\title{
Thymoquinone: A Tie-Breaker in SARS-CoV2-Infected Cancer Patients?
}

\author{
Sawsan Elgohary ${ }^{1,+} \mathbb{D}$, Aya A. Elkhodiry ${ }^{1,+} \mathbb{D}$, Nada S. Amin ${ }^{1,+} \mathbb{D}$, Ulrike Stein ${ }^{2,3,4} \mathbb{D}$ and Hend M. El Tayebi ${ }^{1, * \mathbb{D}}$ \\ 1 Molecular Pharmacology Research Group, Department of Pharmacology and Toxicology, \\ Faculty of Pharmacy and Biotechnology, German University in Cairo, 11835 Cairo, Egypt; \\ sawsanelgohary54@gmail.com (S.E.); ayakhod@gmail.com (A.A.E.); nada.sherif@guc.edu.eg (N.S.A.) \\ 2 Experimental and Clinical Research Center, Charité-Universitätsmedizin Berlin, 10117 Berlin, Germany; \\ ustein@mdc-berlin.de \\ 3 Max-Delbrück-Center for Molecular Medicine, 13125 Berlin, Germany \\ 4 German Cancer Consortium (DKTK), 69120 Heidelberg, Germany \\ * Correspondence: hend.saber@guc.edu.eg; Tel.: +20-100-5566415; Fax: +20-2-27581041 \\ + These authors have contributed equally to the manuscript.
}

Citation: Elgohary, S.; Elkhodiry, A.A.; Amin, N.S.; Stein, U.; El Tayebi, H.M. Thymoquinone: A Tie-Breaker in SARS-CoV2-Infected Cancer Patients? Cells 2021, 10, 302. https://doi.org/10.3390/ cells10020302

Academic Editor: Chae-OK Yun Received: 20 December 2020

Accepted: 28 January 2021

Published: 2 February 2021

Publisher's Note: MDPI stays neutral with regard to jurisdictional claims in published maps and institutional affiliations.

Copyright: (c) 2021 by the authors. Licensee MDPI, Basel, Switzerland. This article is an open access article distributed under the terms and conditions of the Creative Commons Attribution (CC BY) license (https:/ / creativecommons.org/licenses/by/ $4.0 /)$.

\begin{abstract}
Since the beginning of the SARS-CoV-2(severe acute respiratory syndrome-coronavirus2) pandemic, a race to develop a vaccine has been initiated, considering the massive and rather significant economic and healthcare hits that this virus has caused. The pathophysiology occurring following COVID-19(coronavirus disease-2019) infection has given hints regarding the supportive and symptomatic treatments to establish for patients, as no specific anti-SARS-CoV-2 is available yet. Patient symptoms vary greatly and range from mild symptoms to severe fatal complications. Supportive treatments include antipyretics, antiviral therapies, different combinations of broadspectrum antibiotics, hydroxychloroquine and plasma transfusion. Unfortunately, cancer patients are at higher risk of viral infection and more likely to develop serious complications due to their immunocompromised state, the fact that they are already administering multiple medications, as well as combined comorbidity compared to the general population. It may seem impossible to find a drug that possesses both potent antiviral and anticancer effects specifically against COVID-19 infection and its complications and the existing malignancy, respectively. Thymoquinone (TQ) is the most pharmacologically active ingredient in Nigella sativa seeds (black seeds); it is reported to have anticancer, anti-inflammatory and antioxidant effects in various settings. In this review, we will discuss the multiple effects of TQ specifically against COVID-19, its beneficial effects against COVID-19 pathophysiology and multiple-organ complications, its use as an adjuvant for supportive COVID-19 therapy and cancer therapy, and finally, its anticancer effects.
\end{abstract}

Keywords: SARS-CoV-2; COVID-19; cancer; thymoquinone; apoptosis; COVID-19 treatments; anticancer drugs; COVID-19 complications; Nrf2; GRP78; RAS

\section{Introduction}

In March 2020, the WHO declared coronavirus disease -2019 (COVID-19) as a pandemic; this served as the spark that ignited the global race for the development of a vaccine against the novel coronavirus, severe acute respiratory syndrome-coronavirus-2(SARSCoV-2). This was evidently important amidst the sudden and substantial increase in hospitalizations for pneumonia associated with multi-organ disease. The pathophysiology of COVID-19 patients gave clues to suitable supportive and symptomatic treatment of this pandemic; however, no specific treatment against COVID-19 has been found to date. COVID-19 patients have many symptoms that vary in severity, including dry cough, fever [1], sore throat, fatigue, diarrhea, shortness of breath, myalgia, in addition to radiographic and laboratory or biochemical abnormalities [2]. Moreover, cardiovascular manifestations include. Acute cardiac injury, myocarditis, arrhythmia and cardiovascular 
thromboembolism havebeen frequently reported in COVID-19 patients [3]. Furthermore, dizziness, headache, taste and smell dysfunctions, or impaired consciousness has been frequently shown among neurological manifestations in COVID-19 patients [4,5]. Cases involving either viral co-infection or co-infection with both viral and bacterial pathogens that cause pneumonia have been described, particularly in the period following the initial phase of viral respiratory infection [6]. In severe cases, acute lung injury (ALI), acute respiratory distress syndrome (ARDS), respiratory failure, heart failure, sepsis, multiple organ dysfunction, and sudden cardiac arrest occur within a few days [7]. The supportive treatments include antipyretics, antiviral therapies, different combinations of broad-spectrum antibiotics, hydroxychloroquine and plasma transfusion [8]. Cancer patients are at higher risk (two-folds) for COVID-19 and are more likely to develop severe outcomes compared to the general population [9-11]. This is greatly attributed to immunosuppressive conditions, consumption of multiple medications, combined comorbidity, and are more likely to require ventilatory support or ICU admission [12-15]. They also have significantly higher fatality rates (28.6\% compared to $2.3 \%$ for all COVID-19 patients in China) [12]. Patients who have received cancer treatment within 14 days of getting a COVID-19 diagnosis are considered to have a risk factor for developing adverse events, such as ARDS, septic shock, and acute myocardial infarction [12]. Despite this observation, delaying cancer treatment for patients also has well-documented complications [12]. It may seem rather challenging to discover a drug that shows not only antiviral effects specifically against SARS-CoV-2 infection and entry but also antimicrobial (antiviral, -bacterial, -fungal) that protects against SARS-CoV-2 co-infection induced pneumonia, ameliorate respiratory symptoms, as well as acts as an antioxidant thereby protecting against COVID-19 associated multiple organ dysfunction (i.e., cardio-protective, hepato-protective, gastro-protective and protects the kidney from injury). Moreover, this drug should also ideally have anti-inflammatory effects that are sufficient enough to ameliorate COVID-19 induced cytokine storm and whose overall pharmacological effects are consistent with the pathophysiology of COVID-19 in cancer patients.

TQ shows all the above-mentioned effects [16-26]. TQ is the most pharmacologically active ingredient in Nigella sativa seeds (black seeds) extract $[27,28]$. In this review, we will be discussing the potential effects of TQ as a SARS-CoV-2 antiviral drug, its beneficial effects against COVID-19 pathophysiology with a focus on cancer patients, as well as some of its anticancer effects and its use as an adjuvant besides supportive COVID-19 therapy and cancer therapy. To achieve the purpose ofthe review, research was conducted at the States National Library of Medicine (PubMed). For the search in databases, the descriptors used were: "thymoquinone" and "COVID-19" /"SARS-CoV-2" or "cancer", "COVID-19" / "SARS-CoV-2" and "cancer" or "apoptosis", "thymoquinone" and various COVID-19 complications and key molecular pathways. Research papers, books, and published data were reviewed for their relevance to the aim of the review and summarized. Criteria for inclusion were complete, relevant publication, available online, in English, published between 2010 and 2020, with detailed information about participants, methods, and analyses. Data collection was done during August 2020, and data abstracted was in the form of descriptive information, covering the type of samples used, techniques, and findings or effects reported. Bias was limited through the evaluation of the studies through their internal validity rather than the conclusion.

\section{Sars-Cov-2 Structural Features Involved in Entry}

Understanding the structural features of SARS-CoV-2 and its replication is pivotal to focus on molecular targets lessening the viral entry, replication and to fully understand the possible treatment options. SARS-CoV-2 belongs to the family of beta-corona viruses ( $\beta$ CoVs) [29] that have the crown-shaped spike (S) trans-membrane glycoprotein. The human serine proteases participate in viral attachment and RNA entry into the cell. The transmembrane serine protease 9 (TMPRSS2) and endogenous serine proteases, such as furin, prime and cleave the S spike into S1 and S2; this separation is essential for the attachment of 
the SARS-CoV-2 to both the angiotensin-converting enzyme 2 (ACE2) receptor (S1-part of spike) and the cell membrane (S2-part of spike). The attachment of the viral spikes to both the ACE2 receptor and the cell membrane is necessary for successful viral entry and the delivery of its RNA into the cytoplasm [30,31], where it is ready to be translated as mRNA.

Since viral spike attachment to ACE2 receptors is key for its entry and infection of cells, the location of these particular receptors explains a lot about SARS-CoV-2 entry and subsequent COVID-19 symptoms. ACE2 receptors are highly expressed in the lungs (for example, on type 2 alveolar cells (AT2)), nose, oropharynx, kidney proximal tubule cells, bladder urothelial cells, cells of the gastrointestinal tract [12] and myocardial cells [32,33]. This explains why COVID-19 patients do not only experience respiratory problems like pneumonia that might lead to ARDS but may also experience heart, kidneys and digestive tract disorders. The susceptibility and vulnerability of cancer patients to COVID-19 is a multi-factorial issue. Cancer patients tend to have higher levels of ACE2 expression; they are therefore more likely to experience more adverse outcomes [13]. Additionally, TMPRSS and cathepsin L (CTSL), two key enzymes that form essential interactions with the viral spike proteins, were found to be upregulated in certain types of cancer, as shown in Table 1 [34].

Table 1. The differential expression of key enzymes essential for viral spike proteins interaction in different cancer types.

\begin{tabular}{|c|c|c|}
\hline Cancer Type & TMPRSS & CTSL \\
\hline \multicolumn{3}{|l|}{ DLBC } \\
\hline \multicolumn{3}{|l|}{ ESCA } \\
\hline \multicolumn{3}{|l|}{ GBM } \\
\hline \multicolumn{3}{|l|}{ HNSC } \\
\hline \multicolumn{3}{|l|}{ LGG } \\
\hline \multicolumn{3}{|l|}{ PADD } \\
\hline \multicolumn{3}{|l|}{ SKCM } \\
\hline \multicolumn{3}{|l|}{ STAD } \\
\hline \multicolumn{3}{|l|}{ THYM } \\
\hline \multicolumn{3}{|l|}{ CESC } \\
\hline \multicolumn{3}{|l|}{ UCS } \\
\hline \multicolumn{3}{|l|}{$\mathrm{KICH}$} \\
\hline \multicolumn{3}{|l|}{ PRAD } \\
\hline \multicolumn{3}{|l|}{ READ } \\
\hline UCEC & & \\
\hline
\end{tabular}

Abbreviations: TMPRSS, transmembrane serine protease; CTSL; cathepsin L; DLBC, lymphoid neoplasm diffuse large B-cell lymphoma; ESCA, esophageal carcinoma; GBM, glioblastoma multiforme; HNSC, head and neck squamous cell carcinoma; KICH, kidney chromophobe; LGG, brain lower grade glioma; PAAD, pancreatic adenocarcinoma; PRAD, prostate adenocarcinoma; READ, rectum adenocarcinoma; SKCM, skin cutaneous melanoma; STAD, stomach adenocarcinoma; THYM, thymoma; UCEC, uterine corpus endometrial carcinoma [34].

\section{Benefits of Thymoquinone as an Adjuvant in COVID-19}

As mentioned previously, there is no targeted therapy for SARS-CoV-2; supportive treatments against the disease manifestations are undertaken as reviewed in $[35,36]$. Sup- 
portive therapy includes steroids to alleviate the inflammatory status; literature showed that TQ improved oxygenation when combined with steroids and showed protective effects in the lungs [37]. Non-steroidal anti-inflammatory drugs like diclofenac are also used to counteract COVID-19-induced fever and myalgia [38]. Furthermore, COVID-19 and cancer patients are at high-risk of acetaminophen-induced hepatotoxicity as reviewed in [39], diclofenac-induced gastrointestinal side effects as reviewed in [40], along with renal toxicity [41]; luckily, TQ administration protects against acetaminophen-induced hepatotoxicity [42]. In a recent study, TQ protected against diclofenac-induced kidney injury [42,43] and ameliorated GIT toxicity with proton pump inhibition activity [44,45]. Moreover, TQ counteracted the toxic effects of other supportive therapies like gentamicin [46,47], chloroquine [48] and vancomycin [25] and showed a synergistic effect when administered with ranitidine $[44,45]$. Furthermore, tocilizumab, an IL-6 receptor antagonist, has been used in various cancers, such as multiple myeloma and solid tumors, including renal, prostate, lung, colorectal and ovarian cancers, to decrease cancer-associated inflammation. It is used alone or in combination with conventional chemotherapy, as reviewed in [49]. In COVID-19 patients, tocilizumab is given to decrease the viral-induced IL-6 elevation, cytokine storm, and inflammation [50]. TQ is reported as a potent anti-inflammatory drug that decreases IL-6 expression and inhibits NFkB [51]. Hence, giving TQ with tocilizumab could give double beneficial effects in COVID-19 patients. It has been reported that even a single dose of tocilizumab caused gut ulceration in COVID-19 patients [52], and since TQ showed gastroprotective effects, it would be beneficial to investigate the GIT protective effects of TQ in combination with tocilizumab against gut ulceration. Table 2 shows details about the use of TQ as a potential adjuvant therapy to minimize COVID-19 supportive treatments' side effects.

Table 2. Thymoquinone (TQ) as a potential adjuvant therapy to minimize SARS-CoV-2(severe acute respiratory syndromecoronavirus-2) treatments' side effects.

\begin{tabular}{|c|c|c|}
\hline Drug & Beneficial Effect of Thymoquinone as Adjuvant & Reference \\
\hline Acetaminophen & $\begin{array}{l}\text {-Reversal of acetaminophen-induced lipid peroxide increase in ALT, total nitrate/nitrite, } \\
\text { and a decrease in GSH and ATP. } \\
\text {-TQ is effective in protecting mice against acetaminophen-induced hepatotoxicity, liver } \\
\text { cirrhosis and fibrosis via increased resistance to oxidative and nitrosative stress and } \\
\text { decreased serum biomarker enzymes (SGOT, SGPT and ALP) }\end{array}$ & {$[23,53]$} \\
\hline Diclofenac & $\begin{array}{l}\text {-TQ could ameliorate gastrointestinal and renal toxicity induced by high dose diclofenac } \\
\text { treatment. } \\
\text {-TQ administration, with Diclofenac treatment, alleviated the buildup of poly-unsaturated } \\
\text { fatty acids (PUFAs) and diclofenac-induced cell death in kidney cells. }\end{array}$ & {$[42,43]$} \\
\hline $\begin{array}{l}\text { Gentamicin (severe } \\
\text { secondary bacterial } \\
\text { infections) }\end{array}$ & $\begin{array}{l}\text {-TQ showed a protective role against Gentamicin ototoxicity } \\
\text {-TQ significantly prevented the Gentamicin-induced elevations of serum AST, ALT and } \\
\text { LDH activities and also tumor necrosis factor-alpha (TNF- } \alpha \text { ) and total bilirubin levels }\end{array}$ & {$[46,47]$} \\
\hline Chloroquine & $\begin{array}{l}\text {-TQ provides cardio-protective effects by reducing myocardial enzymes following } \\
\text { chloroquine induced cardiotoxicity. }\end{array}$ & [48] \\
\hline Vancomycin & $\begin{array}{l}\text {-TQ reversed the vancomycin induced elevated serum blood urea nitrogen, creatinine and } \\
\text { MDA and showed protective effects against injury }\end{array}$ & [25] \\
\hline $\begin{array}{c}\text { Steroids } \\
\text { (methylprednisolone) }\end{array}$ & $\begin{array}{l}\text {-TQ improved oxygenation and protected lung tissue from hazardous effects of human } \\
\text { gastric juice ( } \mathrm{pH} \text { 1.2) }\end{array}$ & [37] \\
\hline Montelukast & $\begin{array}{l}\text {-TQ and montelukast have dose-dependent effects on cilia beat frequency }(\mathrm{CBF}) \text {, } \\
\text { extending their mechanism of action in respiratory diseases. }\end{array}$ & [54] \\
\hline $\begin{array}{l}\text { Ranitidine, } \mathrm{H} 2 \\
\text { blockers, Proton pump } \\
\text { inhibitors }\end{array}$ & $\begin{array}{l}\text {-TQ+ ranitidine showed synergistic effects and a more significant decrease in ulcer index. } \\
\text {-TQ has novel gastroprotective mechanisms via inhibiting proton pump, acid secretion } \\
\text { and neutrophil infiltration while enhancing mucin secretion, and nitric oxide production }\end{array}$ & {$[44,45]$} \\
\hline
\end{tabular}

Abbreviations: ALT, alanine aminotransferase; AST, aspartate aminotransferase; GSH, glutathione; ALP, alkaline phosphatase; SGOT, serum glutamic oxaloacetic transaminase, SGPT, serum glutamic pyruvic transaminase. 
Thus, far, this literature review has attempted to highlight how TQ could represent a potential adjuvant molecule to COVID-19 standard supportive treatments. To create a full picture, and in order to visualize the true value of TQ in COVID-19 cancer patients, the potential anticancer effects of TQ will be reviewed in the next section, as well as its potential benefit as an adjuvant to chemotherapy.

\section{Anticancer Effects of Thymoquinone}

For more than 50 years, TQ has been known for its anti-neoplastic and chemopreventive effects that have been proven in various types of cancer [55]. Even though TQ is not an FDA-approved drug for cancer therapy, several in vitro and in vivo studies showed that the anticancer activity of TQ is mediated through different pathways involved in proliferation, cell cycle regulation of apoptosis, angiogenesis and cancer metastasis. Apoptosis or programmed cell death is considered to be the most powerful shield against cancer, as it maintains body homeostasis by eliminating aged or diseased cells from the body [56]. This is why mutations or dysregulations in genes regulating apoptosis, such as members of the Bcl-2 family, caspases, p53 and PTEN, are usually present in human cancers [57-60]. The antiproliferative and apoptotic effects of TQ are modulated through several mediators and transcription factors, along with its anti-angiogenic, antimetastatic and chemo, radio-sensitizing effects.

$T Q$ and apoptosis: the downregulation of the antiapoptotic proteins Bcl-2, Bcl-xl, XIAP, survivin, and the upregulation of proapoptotic proteins Bax, p21 and p53 have been associated with TQ-induced apoptosis in various cancers [61-63]. TQ upregulating effect on the proapoptotic transcription factor, p53, was clearly emphasized in numerous in vitro and in vivo studies on cancer models, where TQ induced apoptosis through the upregulation of p53 in breast cancer [64-66], renal cell carcinoma [67], leukemia [68], glioblastoma [69,70], squamous cell carcinoma [71], cervical cancer [72], lung cancer [73], and osteosarcoma [74]. The downstream protein of p53, p21 [75-77], was shown to be upregulated in pancreatic ductal adenocarcinoma as well [78]. The diminished expression of Bcl-2, Bcl-xl, survivin, cFLIP and XIAP following TQ treatment has been established in several cell lines and animal models [79-84]. This diminished expression of Bcl-2 is usually coupled to increased Bax expression as reported in liver cancer [85], leukemia [83], bladder cancer [84], squamous cell carcinoma [86], ovarian cancer [82], and renal cancer [87]. Consequently, the disruption in the Bcl-2/Baxratio, accompanied by reactive oxygen species (ROS) generation induced by TQ inside cancer cells, damages mitochondrial membrane potential, leading to the release of cytochrome $c$. This triggers the intrinsic pathway and activates procaspases 9, 7, 3 and PARP enzyme cleavage. This cascade of events is seen in leukemia/lymphoma [88,89], glioblastoma [79,90], renal cell carcinoma [91], colon [92], brain [93], bladder [84] and ovarian cancers [82]. TQ has been reported to exert a dual effect in which it acts as both pro-oxidant and antioxidant in a dose-dependent manner; the antioxidant effect occurs at low concentration $(<5 \mu \mathrm{M})$ whereas, at higher concentrations $(>20 \mu \mathrm{M})$, it possesses prooxidant property [94]. TQ-induced cell death was mediated through caspase-3 activation in glioblastoma [79], liver [95,96] and cervical cancer [72], while caspases 9 and 3 mediated apoptosis wasseen in lymphoma [88], lung [73], and liver cancer [97]. Moreover, the induction of apoptosis in leukemia was mediated by caspases 8 and 3 involving more than one apoptotic pathway [83].

$T Q$ and cell cycle arrest: since microtubule assembly is important in cell cycle progression, microtubule targeting is a potential mechanism for chemotherapy. TQ was reported to induce cell cycle arrest through depolymerizing microtubule network and disrupting the mitotic spindle organization in A549 lung cancer cells [98]. Several studies reported TQ's cell cycle arrest action through inhibition of cyclin D, cyclin E and cyclin-dependent kinase 2 (Cdk-2) in various cancers [77,92,99,100]. Additionally, a death receptor-mediatedapoptosis was seen with TQ treatment, as TQ caused re-localization of CD95/Fas from cytoplasm to the membrane, enhancing apoptosis in multiple myeloma [101] and enhancing TRAIL/TRAILR expression in medulloblastoma [93], liver [96,97] and lung cancers [76]. 
$T Q$ vs. carcinogen activation: One of TQ's anticancer mechanisms is the suppression of carcinogen activation through inhibiting metabolizing enzymes that are responsible for the biotransformation process of various pro-carcinogens into highly active carcinogens. These reactive carcinogens lead to oxidative damage, or covalent modification of DNA, as well as changes in signaling networks [102-104]. Of particular interest in the cytochrome p450 family are CYP1 members, specifically CYP1A1 phase I enzyme, that was found to be subject to inhibition by TQ, accompanied byan elevation in glutathione and phase II GST enzyme in HepG2 cells [85]. Another anticancer mechanism lies in the anti-inflammatory effects of TQ through inhibiting or modulating cyclooxygenase-2 (COX2) enzyme, which is known to catalyze the formation of the proinflammatory mediators, prostaglandins (PGs). TQ was reported to inhibit COX-2 and PGE in colorectal cancer [105] and cholangiocarcinoma cell lines [80].

$T Q$ vs. angiogenesis and metastasis: $T Q$ is thought to inhibit tumor angiogenesis by inhibiting the expression of vascular endothelial growth factor (VEGF) and its downstream signaling on cholangiocarcinoma [80], stomach [106] and triple-negative breast cancer (TNBC) cells [107]. Moreover, TQ is known to inhibit tumor migration, invasion and consequently tumor metastasis through modulating genes, transcription factors, and proteins responsible for facilitating the migration process [108]. A study on TNBC concluded that TQ exhibited its effect through inhibiting eEF-2K-signaling pathway with its downstream targets, Src kinase, focal adhesion kinase (FAK) and AKT following NF-kB inhibition [109]. Other studies reported that the antimetastatic effect of TQ is exhibited through the inhibition of PI3K/AKT/mTOR pathways, leading to the reversal of endothelial mesenchymal transformation (EndMT). This results in the upregulation of endothelial markers E-cadherin and cytokeratin-19, and downregulation of mesenchymal markers $\mathrm{N}$-cadherin, vimentin, Twist, Slug, Snail, ZEB1 in renal cell carcinoma [110], gastric [111], prostate [112], cervical [113,114], bladder [115] and breast cancer [107,116]. A study on renal cancer cells concluded that the antimetastatic effect of TQ, facilitated by autophagy, is regulated by the AMPK/mTOR pathway [117]. Furthermore, the anti-migratory action of TQ is also exerted by the inhibition of MMP-2, MMP-9 along with integrin B1, urokinasetype plasminogen activator (u-PA), fibronectin, RhoA, and suppression of the activation of JNK, p38, EGFR/IKKa/b/NF-kB-signaling, paxillin and Gai2. This was observed in cancers like TNBC [107], lymphoma [118], glioblastoma [119], renal cell carcinoma [120], colon [121,122] and ovarian cancers [123]. It was also reported that TQ causes downregulation in the TGF- $\beta /$ Smad2/3-signaling pathway and reduction in CXCR4/CXCL12 pathway mediated by NF-kB expression [112,124,125]. Finally, TQ caused inhibition in Wnt/B-catenin signaling with a consequent reduction in $\beta$-catenin target genes, Myc, Axin-2, MMP-7, cyclin D1 and Met in bladder cancer cells [126], and inhibiting ERK1/2 phosphorylation in glioblastoma [127] and lung cancer [128].

$T Q$ vs. gene transcription: the effects of TQ are related and can possibly be linked together by the transcription factors involved. TQ treatment inhibits signal transducer and activator of transcription-3 (STAT3) phosphorylation, causing downregulation of STAT3 and its related genes, Janus activated kinase-2 (JAK2), c-Src, Bcl-2, cyclin D, survivin, VEGF and caspases 3, 7 and 9 in gastric cancer [129]. The downregulation of the PI3K/Akt pathway and NF-kB leads to changes in various related genes, NF-kB p65, GSK3B, XIAP, Bcl-2, VEGF, COX-2, PGE2, inducing apoptosis and inhibiting metastasis in cancer cells [130-132]. Another TQ-affected signaling pathway is the tumor necrosis factor (TNF) pathway, which usually induces NF-kB-signaling, hence modulating apoptosis and inflammation. This pathway was found to be modulated following the treatment of HeLa cells with TQ [133]. Following NF-kB inhibition, NLRP3 inflammasome is inhibited, causing inactivation of caspase- 1 and inhibition of IL-1 and IL-18 in melanoma cells [134]. Moreover, TQ binds to PAK1, causing conformational changes, affecting RAF/MEK/ERK1/2-signaling pathway [105]. Figure 1 summarizes the signaling pathways contributing to carcinogenesis and how TQ inhibits them through its anticancer mechanisms. 


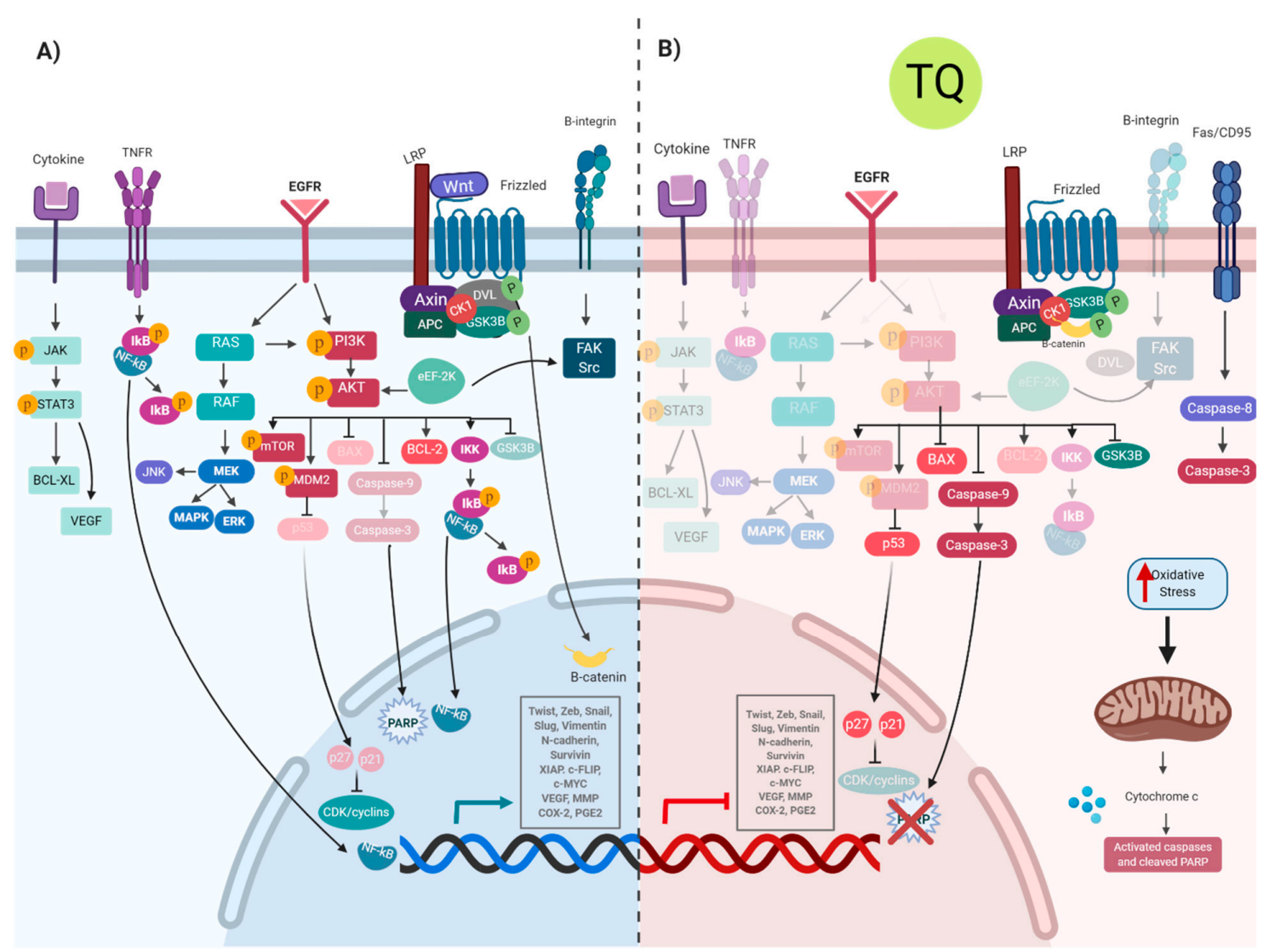

Figure 1. Molecular mechanisms of TQ in cancer development (A) pathways involved in cancer development; (B) pathways inhibited by TQ that appear transparent in the figure while opaque molecules are activated.

$T Q$ as a chemo-adjuvant: adding to the previously mentioned anticancer effects of $T Q$, several studies reported the potentiating effect of combining TQ with chemotherapeutic agents and radiation. It was shown to enhance their anticancer activity, causing chemo- or radio-sensitization, respectively [135-137]. It also reduced or attenuated some treatment-induced toxicities, such as nephropathy or hepatotoxicity, seen with cisplatin treatment [138-141]. Table 3 discusses some of the chemo-modulating effects of TQ in combination with known anticancer drugs. However, as with any other drug, further studies should be done to investigate the standardization of TQ administration when used with cancer drugs, as literature showed that CYP1A2, CYP2C9, CYP2D6 and CYP3A4 were subject to inhibition by $\mathrm{TQ}$, hinting at various potential drug-drug interactions [142].

Table 3. The chemomodulatory/chemosensitizing and protective effects of thymoquinone in combination with chemotherapeutic agents.

\begin{tabular}{|c|c|c|c|c|}
\hline Drugs & Effects & Mechanism & Experimental Model & Reference \\
\hline Paclitaxel & Chemomodulatory & $\begin{array}{c}\text { Downregulating Twist1 } \\
\text { Increase apoptotic cell death and } \\
\text { autophagy }\end{array}$ & $\begin{array}{c}\text { Breast cancer T47D and } \\
\text { MCF-7 cells }\end{array}$ & [143] \\
\hline Docetaxel & Chemomodulatory & $\begin{array}{c}\text { Blocking PI3K/AKT pathways } \\
\text { Enhance Bax, Bid, caspase } 3 \text { and } \\
\text { inhibiting Bcl-XL }\end{array}$ & $\begin{array}{l}\text { Prostate cancer DU145 } \\
\text { and C4-2B cells }\end{array}$ & {$[144,145]$} \\
\hline \multirow{2}{*}{ Doxorubicin } & Chemomodulatory & $\begin{array}{l}\text { Upregulate PTEN Inhibiting AKT } \\
\text { Increasing Bax/Bcl2 ratio } \\
\text { Increase ROS formation }\end{array}$ & $\begin{array}{l}\text { Breast cancer MCF-7 } \\
\text { cells }\end{array}$ & {$[146,147]$} \\
\hline & $\begin{array}{c}\text { Chemomodulatory and } \\
\text { protective }\end{array}$ & $\begin{array}{l}\text { ROS generation } \\
\text { Higher mitochondrial disruption } \\
\text { Maintain cardiac myocyte survival }\end{array}$ & $\begin{array}{l}\text { T cell leukemia cells } \\
\text { Lymphoblastic } \\
\text { leukemia }\end{array}$ & [148-150] \\
\hline
\end{tabular}


Table 3. Cont.

\begin{tabular}{|c|c|c|c|c|}
\hline Drugs & Effects & Mechanism & Experimental Model & Reference \\
\hline Tamoxifen & $\begin{array}{c}\text { Chemomodulatory and } \\
\text { protective }\end{array}$ & $\begin{array}{l}\text { Inactivating AKT, XIAP, bcl-xl and } \\
\text { Bcl-2 } \\
\text { Activating caspase-3, Bax, cytochrome } \\
\text { c and p27 } \\
\text { Hepatoprotective via antioxidant and } \\
\text { anti-inflammatory actions }\end{array}$ & Breast cancer cells & [151-153] \\
\hline 5-fluorouracil & Chemomodulatory & $\begin{array}{l}\text { Downregulate Bcl-2, Wnt / } \beta \text {-catenin, } \\
\text { NF-kB, Cox2, iNOS, VEGF and } \\
\text { PI3k/AKT } \\
\text { Upregulate Bax, Bcl-2, TGF- } \beta 1 \text { and } \\
\text { Samd } 4\end{array}$ & $\begin{array}{l}\text { Colorectal cancer stem } \\
\text { cells } \\
\text { Gastric cancer cells }\end{array}$ & [154-156] \\
\hline Cisplatin & $\begin{array}{c}\text { Chemomodulatory and } \\
\text { protective }\end{array}$ & $\begin{array}{c}\text { Block JAK2/STAT3 pathway } \\
\text { Inhibition of PI3K/AKT pathway } \\
\text { Activating Bax, cytochrome c and } \\
\text { caspases } \\
\text { Reduced hepatorenal toxicity through } \\
\text { antioxidant effect }\end{array}$ & $\begin{array}{c}\text { Esophageal cancer cells } \\
\text { Gastric cancer cells } \\
\text { Oral squamous cell } \\
\text { carcinoma }\end{array}$ & {$[138,139,157-160]$} \\
\hline
\end{tabular}

\section{Thymoquinone's Double Hits in COVID-19 Infected Cancer Patients}

First of all, a recent study showed that TQ could work as an antiviral against SARSCoV-2 since it revealed that TQ mighthave inhibitory activities against its viral protease in silico [161], and several other studies are also working on proving the same effect through insilico computational analysis. This rather interesting observation prompted the analysis of TQ's reported roles in regulating proteins that are involved in COVID-19 as well as in cancer pathogenesis. This review, therefore, aims to summarize in the following sections the common protein targets that are subject to regulation by $\mathrm{TQ}$ and whose roles are furthermore crucial in COVID-19 cancer patients.

Heat shock protein A5 (HSPA5)/GRP78 is also known as immunoglobulin heavy chain-binding protein (BiP) or glucose-regulated protein (GRP78). GRP78 overexpression can occur under a variety of stressful conditions. This overexpression can cause the protein to be, in turn, highly abundant on the cell surface, where it can further potentiate the stressful conditions under which its expression was increased. For instance, overexpression of GRP78 on the cell membranes can increase viral entry via recognition and binding to the substrate-binding domain (SBD) of GRP78. This is true for several viruses [162], and molecular docking also showed that SARS-CoV-2 spike protein could bind to the host cell surface GRP78 [163]. Furthermore, the literature confirmed the in vitro presence of GRP78 protein in airway epithelial cells and in situ protein expression of GRP78 in the respiratory mucosa [164]. Higher serum GRP78 concentrations were found in COVID-19 patients compared to patients with pneumonia and the control group [165]. In another example, GRP78 can be overexpressed in the setting of a malignancy, where its abundance on cancer cell membranes endows antiapoptotic properties to the tumor cell by increasing the levels of antiapoptotic proteins such as Bcl-2 and reducing the levels of proapoptotic proteins, such as Bax. Ultimately, this results in promoting tumor survival, progression, angiogenesis, invasion, metastasis, as well as resistance to therapy [166]. This has been observed in various types of cancers [167-171].

HSPA5/GRP78 and TQ: TQ decreases the expression of HSPA5/GRP78 and improved mitochondrial function [172]. Furthermore, molecular docking showed that TQ might interfere with SARS-CoV-2 attachment to HSPA5 by tightly binding to this protein on the cell surface [173]. Collectively, TQ produces a dual hit, where it tightly binds to HSPA5/GRP78, reducing its expression. Thus both reduces the risk of SARS-CoV-2 infection and decrease chemotherapy resistance, cancer invasion, metastasis, and survival, as illustrated briefly in Figure 2 [173]. 


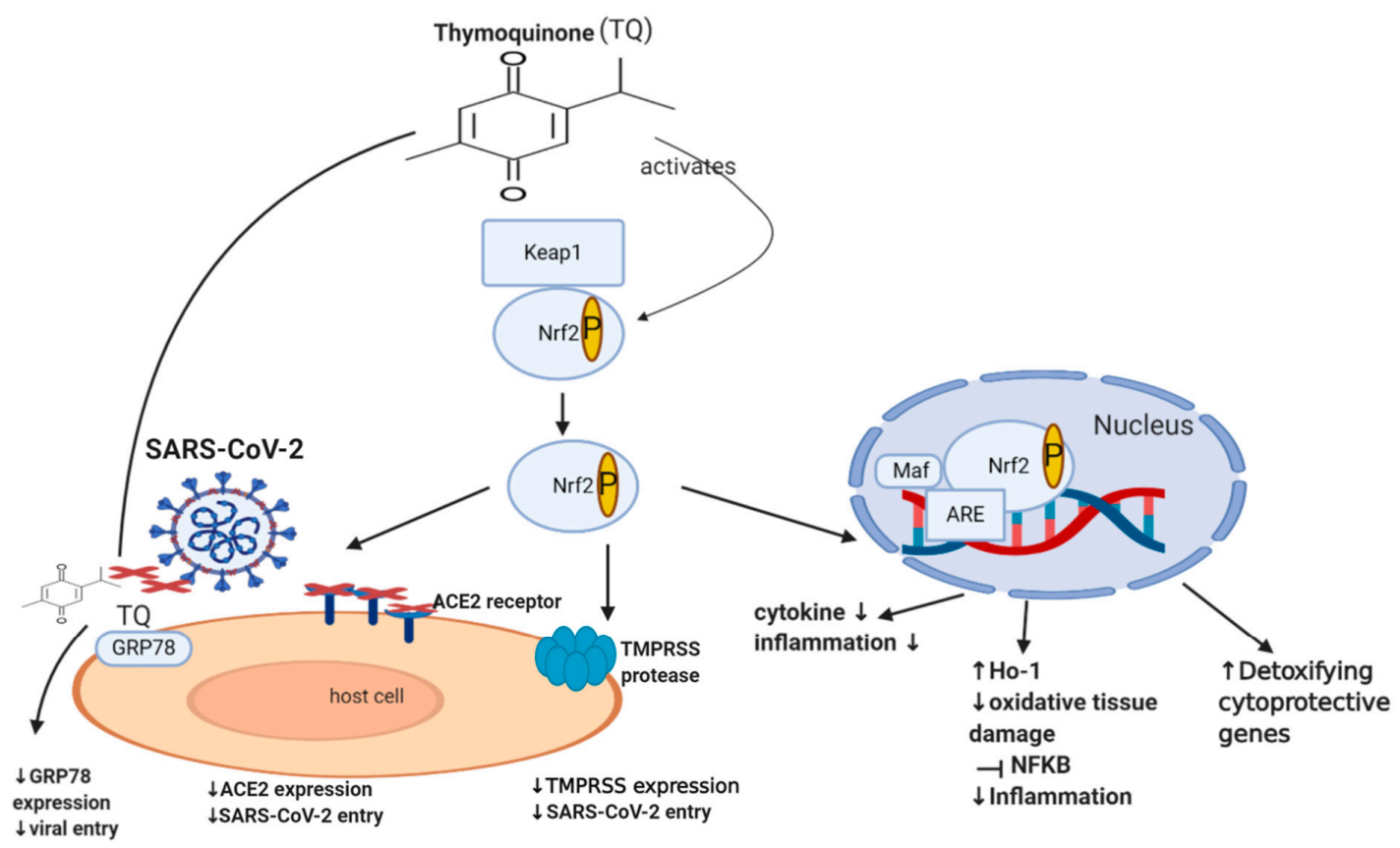

Figure 2. Effect of TQ on Nrf2, GRP78 and SARS-CoV-2 infection. A diagram showing the effect of TQ on Nrf2; it activates Nrf2 by phosphorylation, causing its translocation inside the nucleus, binding to ARE (antioxidant response element) and Maf. This binding results in the reduction of NF-kB, cytokine production, inflammation, oxidative damage and an increase in detoxifying cytoprotective genes and enzymes such as the HO-1 enzyme. Moreover, TQ decreases GRP78 expression, angiotensin-converting enzyme 2 (ACE)-receptor expression and hence decreases viral entry.

$\mathrm{Nrf2}$ (nuclear factor erythroid-derived 2 related factor 2) is an important transcription factor that counteracts oxidative stress, where it acts as a sensor of oxidative stress, preventing genomic instability. It regulates about 250 genes involved in cellular homeostasis, including detoxifying enzymes, antioxidant proteins, and cytoprotective proteins [174]. Under normal physiological conditions, Nrf2 is sequestered by the cytoplasmic keap1 (Kelch-like ECH-associated protein 1), which maintains the Nrf2 at low levels through targeting it for proteasomal degradation (ubiquitination) [175]. Disruption of Nrf2 homeostasis can be seen in various settings, including viral infection and cancer. During a viral infection, intracellular expression of viral proteins leads to an increase in the oxidative stress of a cell. This leads to the dissociation of Nrf2 from keap1, which consequently prevents its ubiquitination $[176,177]$. Nrf2 is now able to translocate to the nucleus and activate the transcription of detoxifying, cytoprotective genes such as heme oxygenase (HO-1) [178,179]. This mechanism is also involved in the setting of cancer, where Nrf2 is additionally able to protect a cell from chemical and radiation-induced carcinogenesis [180-183]. Moreover, literature revealed that $\mathrm{Nrf2}$ is able to enhance innate immune system activity, as well as participate in the inhibition of inflammatory cytokine expression, including IL-1 $\beta$, IL-6, and NF-kB, ultimately decreasing inflammation [184-186]. Although some studies show that the continuous activation of Nrf2, as a result of excessive levels of ROS, could have deleterious effects on the host cell $[187,188]$, it usually does not happen in viral infections since the virus needs to keep optimal oxidative stress levels allowing it to maintain viral metabolism without causing death in the host cell [189]. A recent study in 2020 involving 40 patients showed that the severity of COVID-19 is inversely associated with Nrf2 expression and directly linked to age and intensity of inflammatory response [190]. Interestingly, recent studies showed that Nrf2 deficiency upregulates ACE2 receptors, while activation of Nrf2 downregulates ACE2 receptors, with Nrf2 knock-out mice showing enhanced ACE2 expression. In cultured immortalized renal proximal tubule cells, treatment with Nrf2 inhibitor (Trigonelline) or transfection with Nrf2 small interfering RNA led to an increase in ACE2 transcription [191]. The exact mechanism of how Nrf2 downregulates the 
ACE2 receptor remains unclear. Additionally, Nrf2 activators downregulate the mRNA expression of TMPRSS2 [192,193] via upregulating TMPRSS2 inhibitors PAI-1 plasminogen activator inhibitor-1 encoded by the SERPINE gene (SERPINE/PAI-1) [192] and secretory leukocyte protease inhibitor (SLPI) [193]. This may highlight the important role of Nrf2 in downregulating TMPRSS2, ACE2 receptor expression and subsequently decreasing SARS-CoV-2 infection load. Despite the numerous cytoprotective mechanisms of Nrf2, it still appears to be a double-edged molecule since there is cumulative evidence establishing the fact that Nrf2 is one of the pathways that drive cancer progression, spread or metastasis, and chemo-resistance [194-203], and hence further dedicated studies may still be required.

Nrf2 and TQ: in keratinocytes, TQ works as a pro-oxidant that activates Nrf2 and increases its nuclear accumulation, leading to increased mRNA and protein expression of HO-1 [204], enhancing its binding to ARE, thus decreasing ACE2 expression, as demonstrated in Figure 2 [205]. During the course of COVID-19, white blood cells become activated, releasing excessive, prolonged inflammatory cytokines, leading to what is called the cytokine storm, acute respiratory distress syndrome, multiple organ dysfunction, and even death $[206,207]$. In addition, SARS-CoV-2 might invade the central nervous system inducing neurological diseases [208] manifested as headache, nausea, and vomiting. TQ showed inhibitory effects on NF-kB mediated neuroinflammation, as mentioned in Table 4, reporting other TQ effects in COVID-19-induced neurological disease. Altogether, TQ activates Nrf2 [204] that decreases ACE2 expression [205], potentially decreasing SARS-CoV-2 infection, inhibiting NF-kB [205], thus ameliorating the COVID-19-associated cytokine storm and inflammation. This would indeed also be beneficial in cancer patients who suffer from elevated cytokines and inflammation. On the other hand, Nrf2 appears to have contrasting roles in cancer patients, where it protects against chemical and radiation-induced carcinogenesis [180-182] but also leads to tumor-promoting effects. It would be beneficial to investigate the effects of TQ on Nrf2/HO-1/NF-kB in cancer patients with COVID-19.

Table 4. The beneficial effects of TQ against COVID-19 pathophysiological effects.

COVID-19

Complications

Cardiac damage
Thymoquinone

\section{References}

-Protects against hyperlipidemia, cyclophosphamide, doxorubicin and diesel exhaust particle-induced cardiac damage or changes

-Counteracts sepsis-induced elevation in p62 and increases beclin-1 expression

-Reduced infarct size, improved cardiac function, reduced myocardial enzyme LDH

and CK-MB activities and inhibited oxidative stress
-Inhibited nuclear factor kappa-B (NF-kB) in lung tissue

-Ameliorates the pathological changes of chronic asthma, inhibits inflammatory changes by antagonizing IL-4/5, and a single dose prevented asthma in the guinea pig model

-Showed anti-neoangiogenic effects through inhibition of expression of VEGFR2/PI3K/Akt-signaling pathway

-Decreased the inflammatory and apoptotic index levels in rats exposed to cigarette smoke and showed anti-inflammatory and cytoprotective effects against cigarette smoke-induced COPD and LPS induced acute lung injury by COX inhibition

-Downregulated pro-fibrosis genes and decreased oxidative stress in lung fibrosis -Counteracted emphysema in air alveoli, lymphoid hyperplastic cells activation surrounding the bronchioles, inflammatory cell infiltration

-Ameliorated pulmonary arterial hypertension, Induced relaxation of the precontracted pulmonary artery and caused a decrease in the tension of pulmonary arterial rings precontracted with phenylephrine

-Reduced alterations in lungs and inflammatory markers induced by cyclophosphamide and toluene, decreased lipid peroxidation and restored antioxidants

-Showed inhibitory effects on the aggregation of inflammatory cells in bronchoalveolar lavage (BAL) fluid and in lung tissues -Significantly decreased serum $\operatorname{IgE}$ and showed superior inhibitory effects on iNOS and TGF- $\beta 1$ 
Table 4. Cont.

\begin{tabular}{|c|c|c|}
\hline $\begin{array}{l}\text { COVID-19 } \\
\text { Complications }\end{array}$ & Thymoquinone & References \\
\hline $\begin{array}{l}\text { Liver injury, } \\
\text { elevated liver } \\
\text { enzymes }\end{array}$ & $\begin{array}{l}\text {-Effectively improved the plasma and liver antioxidant capacity and enhanced the } \\
\text { expression of liver antioxidant genes of hypercholesterolemic rats } \\
\text {-Protects against oxidative liver damage and ductular proliferation } \\
\text {-Reduced liver injury and tumor markers expressions;thus its beneficial in the treatment } \\
\text { of hepatocellular carcinoma } \\
\text {-Protected against cyclophosphamide, tamoxifen, cypermethrin, cadmium, anti-TB } \\
\text { drugs, aflatoxinB1, acetaminophen and paracetamol-induced } \\
\text { hepatotoxicity/necrosis/cirrhosis and fibrosis by decreasing the elevated ALT, AST and } \\
\text { ALP, enhanced regeneration after tissue damage, decreased oxidative protein damage } \\
\text { and increased SOD expression and GSH } \\
\text {-Ameliorated liver fibrosis via blocking TLR4 expression and PI3K phosphorylation on } \\
\text { the activated hepatic stellate cells } \\
\text {-Reduced thioacetamide-induced liver fibrosis and inflammation by decreasing } \\
\text { proinflammatory cytokines, inhibiting PI3K phosphorylation and enhanced p-AMPK } \\
\text { and liver kinase B (LKB-1) }\end{array}$ & $\begin{array}{c}{[20,23,24,53,153,} \\
224-232]\end{array}$ \\
\hline
\end{tabular}

-Attenuated oxidative stress and inflammation-reducing renal ischemia-induced damage and several drugs-induced nephrotoxicities

-Reversed the vancomycin and doxorubicin-induced nephrotoxicity, reversed elevated Kidney damage serum blood urea nitrogen, creatinine, MDA and urinary albumin excretion -Protected kidney against urinary tract infections (Escherichia coli) induced pyelonephritis

-Showed protective action against cypermethrin induced shrinkage of glomeruli and necrosis of renal tubules in kidneys (in mice)

-Induced a significant increase in expression of neuroprotective proteins such as biliverdin reductase-A, 3-mercaptopyruvate sulfurtransferase, glutaredoxin-3, and mitochondrial Lon protease, a significant decrease in expression of inflammatory cytokines, and NF-KB pathway

-Decreased malondialdehyde and nitric oxide metabolites in the brain

Neurological -Enhanced the thiol content and superoxide dismutase and catalase activities and serum disease, cognitive T4 level decline -Protected against PTU-induced memory impairments in rats -Reversed learning and memory impairments, brain tissue-oxidative damage in hypothyroid juvenile rats and alleviated changes in the hippocampal lipid peroxide level and SOD and AChE activities

-Have a protective effect on learning and memory function. It significantly increased the expression of Nrf2, HO-1 proteins and SOD in the hippocampus

-Showed significant antimicrobial activity against anaerobic bacteria, thus can be used against diarrhea

-Prevented and significantly reduced the appearance of diarrhea and body weight loss in mice and ameliorates dextran sulfate sodium-induced colitis

GIT -Inhibited proton pump, acid secretion and neutrophil infiltration, while enhancing mucin secretion, reduces ulcer index, markers of oxidative stress and nitric oxide production

-TQ+ ranitidine showed synergistic effects and a more significant decrease in ulcer index -Suppressed spontaneously contracting rabbit jejunum and also relaxed high $\mathrm{K}$ induced contractions in the jejunum and guinea-pig ileum, thus can be used in colic and diarrhea

-Inhibited histamine production

Allergy, allergic
conjunctivitis

-Decreases the symptoms of allergic conjunctivitis almost the same as dexamethasone

-Suppressed the Total IgE, OVA-specific IgE and Recruitment of Inflammatory cells

-Alleviated allergic inflammation and may be valuable for treating allergic rhinitis

\section{-Decreased lipase \amylase ratio}

Acute pancreatitis and elevated lipase
-Decreased oxidative stress markers, pancreatic 4-hydroxynonenal (4-HNE), protein

carbonyl content and protected pancreatic acinar cells from oxidative stress

-Attenuated GSH depletion and increased the activity of GST

\footnotetext{
Abbreviations: LDH: lactate dehydrogenase; CK-MB: creatininekinase-MB; ARDS: acute respiratory distress syndrome; COPD: chronic obstructive pulmonary disease.
} 
The Renin-Angiotensin System (RAS) is a homeostatic loop that begins when the hepatic angiotensinogen is converted into angiotensin I (ATI) by the renal renin enzyme. This loop then involves two arms; the ACE enzyme (from the lungs) converts ATI to angiotensin II (ATII), increasing its circulating levels. This mediator is implicated in vasoconstriction, fibrosis, hypertension, and inflammation. The second arm involves the conversion of ATII to AT1-7 by ACE2, which carries out the opposite effects of its precursor, ATII [242,243]. Many of the cardiovascular symptoms, as well as multiple organ damage seen with COVID-19, can be linked to RAS-induced dysregulation [244]. In fact, patients with COVID-19 tend to have significantly higher levels of circulating ATII compared to healthy individuals, and the findings of various studies that were conducted on autopsies [245] suggest that SARS-CoV-2 may cause downregulation of ACE2 receptors. This finding, along with receptor internalization upon viral binding, further contribute to the increase in ATII levels and the imbalance between the pro- and anti-inflammatory roles of the RAS, ultimately causing the proinflammatory role of the RAS to predominate [13], endowing procoagulant properties to endothelial cells [245].

The increased ATII enhances the activity of NADPH oxidase, increasing ROS, leading to induction of vascular smooth muscle cell (VSMC) proliferation, migration, atherosclerosis [246], and hypertension via increased oxidative stress, inflammatory reactions and production of vasoconstrictors while decreasing the vasodilator nitric oxide (NO). Thus, inhibition of VSMC proliferation and migration would be beneficial in preventing atherosclerosis and avoiding cardiovascular complications [247]. Peroxisome proliferator-activated receptor $\gamma$-coactivator $1 \alpha$ (PGC-1 $\alpha$ ) was shown to attenuate ROS generation, thereby limiting ATII-induced rat VSMC proliferation [248]. Moreover, AMPK activation attenuates ATII induced VSMC proliferation, and PPAR $\gamma$ has been reported to have antiproliferative effects in multiple cancers $[249,250]$. The ramifications of the prolonged basal inflammatory state observed in the setting of malignancy can be closely mirrored in other statesof inflammation, including hypertension, obesity, diabetes, and even in COVID-19 patients with the aforementioned comorbidities. This surge in inflammatory cytokines increases the production of local and systemic ATII [251]. Increased levels of ATII in cancer patients has been associated with shortened survival [252]. It is therefore hypothesized that two hits contribute to the hyper-inflammatory response that is observed in COVID-19 patients with comorbidities; the first hit was resulting from the chronic state of inflammation, which increases the activity of the ATII proinflammatory axis, and the second hit resulting from SARS-CoV-2 itself, via the internalization of ACE2 receptors, and the decrease in the activity of the anti-inflammatory ACE2 axis [253]. Together, these two hits increase tissue damage as well as the risk for multiple organ failure.

$T Q$ and RAS/ATII: the effect of TQ on ATII can be seen when TQ $(40 \mathrm{mg} / \mathrm{kg})$ is injected intraperitoneally $30 \mathrm{~min}$ before ATII $(300 \mathrm{mg} / \mathrm{kg})$ intravenous injection. This significantly blunted the rise in systolic blood pressure, mean arterial pressure and heart rate that wasinduced by ATII. Thus, the antagonistic effect of TQ on ATII appears to be beneficial in both COVID-19 patients and cancer patients [254]. TQ markedly inhibited ATIIinduced VSMC proliferation, migration, and oxidative stress. It also reversed the elevated NADPH oxidase activity and ROS induced by ATII [255]. In addition, TQ enhanced the expression of p-AMPK, PPAR $\gamma$, and PGC- $1 \alpha$ that were inhibited by ATII. These particular effects of TQ were abolished by AMPK inhibitor or PGC-1 $\alpha$ siRNA transfection [255]. Furthermore, TQ reduced oxidative stress, lipid peroxidation (specifically renal MDA), renal TNF- $\alpha$ in unilateral ureteral obstruction (UUO), and increased antioxidant enzymes (SOD, catalase). Meanwhile, it significantly decreased obstruction-induced apoptotic cell death and decreased ATII renal expression [256]. Thus, collectively, TQ improves renal oxidative damage, apoptotic cell death, TNF- $\alpha$ expression and also prevents the upregulation of ATII in UUO injured rats [257]. Looking at the bigger picture, TQ can be a promising drug in ameliorating COVID-19-induced RAS dysregulation, counteracting multiple organ failure in COVID-19 cancer patients. 


\section{The Significance of Thymoquinone in Other Pathological Processes in COVID-Cancer Patients}

Platelet hyper-reactivity, the novel coronavirus, promotes a state of hypercoagulation [13] and additionally predisposes some patients to thromboembolic events through altering platelet function. Literature showed that resting platelets from COVID-19 patients had increased basal $P$-selectin expression, aggregated faster, and showed increased spreading on both fibrinogen and collagen. The increase in platelet activation and aggregation could partially be attributed to increased MAPK pathway activation and thromboxane generation $[258,259]$. Interestingly enough, TQ is able to ameliorate platelet hyper-reactivity by suppressing COVID-19-induced MAPK activation, and another study showed that TQ triggers apoptosis of blood platelets in a PI3K-dependent manner. Hypercoagulation in COVID-19 is typically characterized by elevated levels of fibrinogen and D-dimer, increased prothrombin time (PT), activated partial thromboplastin time, mild thrombocytopenia, elevated factor 8 and Von Willebrand Factor [12]. D-dimer levels are especially increased in critically ill patients who are administered into the ICU and is used as a prognostic factor [13]. Evidence suggests that SARS-CoV-2-induced release of proinflammatory cytokines of the innate immunity, either in close proximity to the affected organ (alveolar cells of the lung) or in the bloodstream, represents the culprit of the inflammatory process $[12,206]$. Concerning cancer patients, studies showed that multiple myeloma (MM) patients have an increased risk for venous thromboembolism (VTE) $[258,259]$. In this regard, TQ has been shown to reverse cancer-associated thrombosis and thus can be used as a preventive anti-coagulant and/or as a supplement to existing chemotherapies, producing a double protective effect in COVID-19 infected cancer patients, counteracting the viraland cancer-induced platelet hyperreactivity [260-262].

With regard to inflammation and multiple organ failure; treatment approaches of COVID19 that aim at targeting the viral replication cycle may not be enough for promoting host survival, as it is also necessary to target the virus-induced cytokine release syndrome (CRS) that leads to multiple organ damage and ARDS [263]. Some of the proinflammatory cytokines that are locally and systemically elevated include IL- $1 \beta$, interferon- $\gamma$ (IFN- $\gamma$ ), IL-1, IL-6, and monocyte chemoattractant protein 1 (MCP-1). They have been detected in critically ill patients, and they were found to correlate to disease severity [264,265]. Furthermore, upon SARS-CoV-2 entry into the host cell, the disruption of the intracellular environment via ion redistribution results in the activation of NLRP3 inflammasome that increases the secretion of proinflammatory cytokines: IL-1 $\beta$, IL-18, IL-6 and TNF, further contributing to the imminent cytokine storm and tissue inflammation during respiratory illness [266]. In this context, TQ could have a promising anti-inflammatory role, where it significantly decreases the mRNA expression of the aforementioned proinflammatory cytokines, IL-18, IL-1 $\beta$ and TNF- $\alpha$, and inhibits IL-6-signaling [16,17,267-269]. In cancer patients, inflammasomes are also overexpressed, leading to an increased inflammatory status $[270,271]$. The disastrous effect of NLRP3 inflammasome in melanoma is owed to its suppression of NK cell activation, necessary for the release of IFN- $\gamma$ and killing of tumor cells, therefore, ultimately increasing lung metastasis [272,273]. Closely examining the molecular mechanisms of inflammasome complexes in different cancer types revealed that the overexpression of IL-1 $\beta$ causes mobilization of myeloid-derived suppressor cells (MDSCs) and induces gastric cancer [274], while signaling of IL-1 drives the accumulation of MDSCs, promoting primary and metastatic mammary tumors [275]. Moreover, the inflammatory mediator IL-18 is known to accumulate in cancer patients with the ability to fine-tune the activation status of NK cells, depending on the amount of IL$18[12,276]$. It is worth noting that inflammasomes do not always show tumor-promoting effects; in fact, they showed protective roles in some cancer types [277]. Since TQ is an NLRP3 inhibitor, this would consequently decrease the secreted IL-1 $\beta$, IL-18 and IL-6 and ameliorate pain and inflammation in COVID-19 cancer patients. In addition to NLRP3, eicosanoids play a critical role in the progression of inflammation, fever, allergies, cancer, and pain $[206,273,275]$. Although the role of eicosanoids in COVID-19 is not well 
characterized, it is believed that cell debris is able to initiate an eicosanoid and cytokine storm in the context of inflammatory diseases. TQ is also able to target arachidonic acid metabolism [278]. Targeting the upstream portion of the eicosanoid storm will potently inhibit the cytokine storm formation, protecting against inflammation-mediated multiple organ damage in COVID-19 patients.

Oxidative stress: oxidative damage is an important aspect in which COVID-19 has a notable impact on cancer patients. The analysis showed that interactions between viral proteins and some of the components of the ROS pathway had been implicated in different cancer types. These interactions may be exploited by SARS-CoV-2 to disrupt the basic processes that modulate mitochondrial respiration, metabolism, and oxidative stress, including certain pathways that are known to be important for the development of tumors [279]. TQ happens to demonstrate potent antioxidant properties, where it significantly attenuates glutathione (GSH) depletion and increases the activity of the glutathione-S-transferase (GST) enzyme. It significantly decreases oxidative stress markers, including thiobarbituric acid reactive substance (TBARS), which is elevated in several cancer types like colon and cervical cancer $[280,281]$. Furthermore, TQ induces the expression of several detoxifying enzymes, including glutathione reductase, superoxide dismutase 1 (SOD1), catalase, and glutathione peroxidase 2 (GPX) $[16,19,20]$. The reduction of oxidative stress, therefore, gives a protective effect against multiple organ failure associated with COVID-19 and cancer patients.

Myocardial injury: cardiac injury is significantly associated with fatal outcomes in COVID-19. In sepsis, elevated plasma levels of troponin-T (c-Tnt) are an important indicator of cardiac damage. Severe cases of COVID-19 showed elevated plasma levels of c-Tnt and were in higher need of mechanical ventilation compared to those with normal Tnt levels. They also had more frequent malignant arrhythmias and needed glucocorticoid therapy [282]. Increased inflammatory cytokines can directly or indirectly cause cardiac damage, but the precise mechanism of myocardial dysfunction-induced sepsis is still unclear. This is also common in cancer patients, where cardiac injury is a risk factor for mortality and may be indicated by elevated levels of troponin and BNP biomarkers, which could result from either the malignancy or the treatment regimen [13]. For example, certain anticancer medications cause patients to suffer from cardiotoxicity presenting as ischemia or vasospasm. An example of this is CAR-T therapy, which may result in CRS, and proteasome inhibitors, which may cause heart failure [283]. Literature showed that TQ significantly decreased TnT levels and markedly reduced cardiac tissue-inflammatory cell infiltration in the cecal ligation and puncture (CLP)-induced-sepsis group. Additionally, P62 and beclin1 are two major proteins in autophagy, and previous literature showed that P62 expression is increased, while beclin1 is decreased in cardiac damage and in sepsis [284-286]. TQ significantly decreased P62 and increased expression of beclin1 in CLP mice, thus decreasing sepsis-induced cardiac damage.

Lung injury: COVID-19 causes respiratory symptoms including breathlessness, pneumonia, severe ARDS, lung fibrosis and injury [287]. Studies show that TQ has promising effects in lung protection; it protects against injury and fibrosis induced by LPS, toluene, and cyclo-phosphamide. It also induces the relaxation of the precontracted pulmonary artery $[213,214,216-220]$. Moreover, TQ inhibits inflammation, neoangiogenesis, and vascular remodeling in various asthmatic models [215,221-223]. It also counteracts several processes, including emphysema in air alveoli, activation of hyperplastic lymphoid cells surrounding the bronchioles, and inflammatory cell infiltration [216]. According to Jaber S. Alqahtani et al., 2020, chronic obstructive pulmonary disease (COPD) patients were at a higher risk of more severe COVID-19, especially in smokers, as they were seen to have higher expression of ACE2 in their airways [288,289]. TQ decreases the inflammatory and apoptotic index levels in rats exposed to cigarette smoke and shows anti-inflammatory and cytoprotective effects, as summarized in Table 4 [22]. 
Liver injury: liver injury is a critical, life-threatening COVID-19 complication [290]. It is common in cancer patients, as some chemotherapeutic agents like cyclophosphamide [291,292] and tamoxifen cause hepatotoxicity [293], as reviewed in De La Vega et al. [294]. This demonstrates the potentially fatal ramifications of COVID-19 in cancer patients. TQ shows several promising hepatoprotective effects against toxicities and fibrosis $[20,23,24,53,224,226-228,230-232]$, where it protects against chemotherapy-induced hepatotoxicity through reducing liver injury and tumor markers expression, hinting atthe use of TQ in the treatment of hepatocellular carcinoma [153,225,229]. Altogether, using TQ provides a dual benefit, where it protects against both COVID-19-induced and chemotherapy-induced hepatotoxicity.

Kidney injury: this is another COVID-19 related serious complication as reviewed in [295]. Certain chemotherapeutic regimens make cancer patients more susceptible to nephrotoxicity [296]. TQ shows protective effects in the kidneys through ameliorating oxidative stress and reversing the nephrotoxic effects of various drugs and infections $[24,25,226,233,234]$, as summarized in Table 4 . Moreover, TQ shows reno-protective effects in sepsis-induced AKI. Since AKI is majorly mediated by dysregulated activation of inflammasomes and proinflammatory cytokines, the aforementioned anti-inflammatory properties of TQ also appear to be of significant benefit in this context [17], where TQ decreases apoptosis of kidney cells and alleviates AKI. Finally, NFKB is the main transcription regulator of inflammatory genes and has crucial roles in inflammation and the pathophysiology of sepsis. TQ reverses the increased NFKB expression in the kidney from septic mice. Collectively, TQ contributes to the alleviation of sepsis-induced AKI by regulating pyroptosis, proinflammatory cytokines, and apoptosis-related expression [17].

Neurologic/cognitive manifestations associated with COVID-19: these manifestations include headache, memory loss, mood changes, vision changes, hearing loss, loss of smell, loss of taste, impaired mobility, limb numbness, tremor, fatigue and myalgia [297]. This is along with cases of encephalitis, necrotizing hemorrhagic encephalopathy, stroke, and epileptic seizures as reviewed in [298]. TQ shows several neuroprotective effects, as summarized in Table 4 [191,236].

TQ and gastrointestinal (GIT) manifestations associated with COVID-19: these include diarrhea, loss of appetite, nausea/vomiting and abdominal pain as reviewed in [299]. TQ shows a promising effect against anaerobic bacteria, thus would alleviate diarrhea. It also acts as a gastroprotective agent, proton pump inhibitor and enhances mucin secretion, which would be additionally beneficial in cancer patients suffering from GIT symptoms $[18,26,44,45,238]$.

$T Q$ and ocular manifestations and conjunctivitis associated with COVID-19 [300]: literature showed that TQ decreases the symptoms of allergic conjunctivitis nearly as effectively as dexamethasone [239], possibly ameliorating COVID-19 associated conjunctivitis.

Pancreatitis: pancreatic inflammation, along with increased lipases associated with COVID-19, can be reduced with TQ since it has been shown to decrease lipases and protect the pancreas against oxidative stress [16,241].

Collectively, TQ showed protective effects in the heart, lungs, kidney, liver, GIT, pancreas and alleviated oxidative stress as summarized in Figure 3 and reported in detail in Table 4 . 


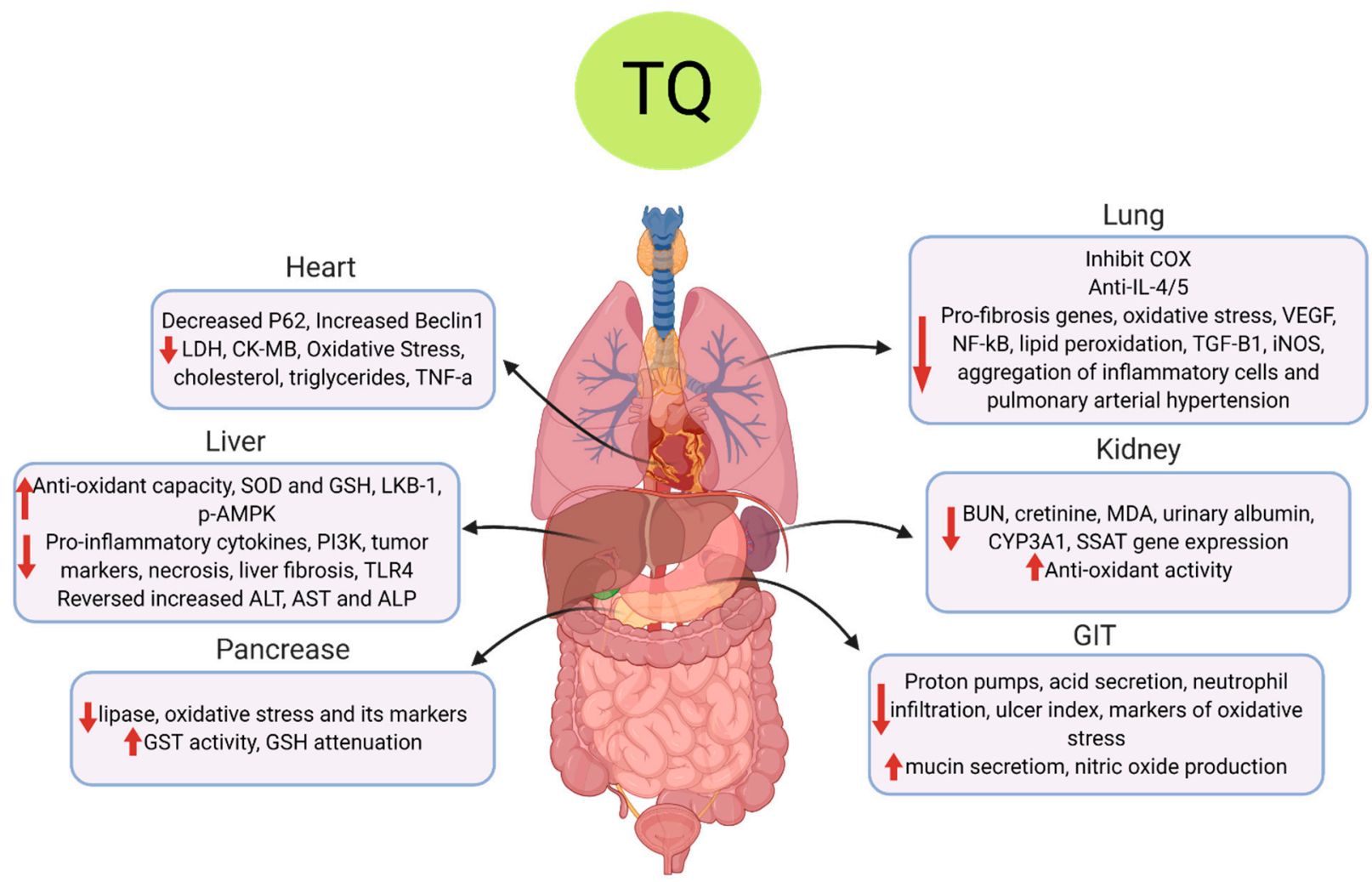

Figure 3. The multifunctional effects of TQ on COVID-19-associated pathophysiology. The diagram summarizes the main organ-related and organ protective effects of TQ on the main body organs. In the heart, TQ decreases cardiac enzymes, cholesterol, triglycerides and inflammatory cytokines. In the liver, TQ increases antioxidant enzymes and decreases proinflammatory genes and cytokines, elevated liver enzymes and liver fibrosis. In the pancreas, TQ increases antioxidant capacity by increasing glutathione-S-transferase (GST) enzyme and glutathione (GSH) levels while decreasing lipase and oxidative stress. In the lungs, TQ inhibits cyclooxygenase (COX) enzyme, IL-4/5 levels, NF-kB, vascular endothelial growth factor (VEGF), transforming growth factor- $\beta 1$ (TGF- $\beta 1$ ), oxidative stress, inducible nitric oxide synthase(iNOS) enzyme, lipid peroxidation, pro-fibrosis genes and pulmonary arterial hypertension;in the kidney, TQ decreases kidney markers, blood urea nitrogen (BUN), creatinine, malondialdehyde (MDA) and albumin and increases antioxidant activity. In the gastrointestinal tract (GIT), TQ inhibits proton pump, acid secretion, ulcer index, neutrophil infiltration and oxidative stress markers and increases mucin secretion and nitric oxide (NO) production.

\section{Conclusions}

The clinical spectrum of COVID-19 can generally range from patients who are paucisymptomatic to those experiencing severe respiratory failure and ARDS, and finally, to those who suffer from systemic manifestations and multiple organ failure. Cancer patients are of particular interest in light of this pandemic; they are more liable to experience a more severe clinical course of the disease, owing to multiple confounding factors, such as increased basal inflammatory state, increased oxidative stress, as well as the very likely presence of existing comorbidities other than the malignancy itself. Amidst the eagerness to vaccinate populations against COVID-19, the aforementioned points still justify the rather meticulous hunt for a drug or an agent that would ideally provide COVID-19 infected cancer patients with double benefits, positively affecting the courses of both their malignancies and the viral infection. In this review, we have hoped to shed light on TQ from Nigella sativa seeds and how it has been shown throughout numerous studies to have potential beneficial and protective effects in general and in COVID-19-infected cancer patients in particular, with significantly lower incidences of side effects. First, it reduces the probability of SARS-CoV-2 entry into cells. Second, it helps ameliorate the deleterious effects of CRS in COVID-19-infected cancer patients, thereby protecting against multiple organ damage. 
Additionally, it is particularly beneficial for cancer patients because it could potentially alleviate multiple chemotherapy-induced toxicities, exhibit anticancer effects, as well as exhibit chemo- and radio-sensitizing effects. Figure 4 summarizes the common molecular targets and effects of TQ that are beneficial in both cancer and COVID-19 patients. Altogether, TQ is a promising solution that may win the battle against COVID-19 and cancer. While TQ is not an FDA approved drug for the treatment of cancer or COVID-19; during the past year, onephase 3 clinical trial was done while threephase 2 clinical trials are currently studying the effect of Nigella sativa extracts on immunity and clinical outcomes of COVID-19 patients as per clinicaltrials.gov (Identifier number: NCT04347382, NCT04472585, NCT04401202 and NCT04553705). It is clear that further clinical trials investigating the use of TQ in numerous cancers need to be implemented.
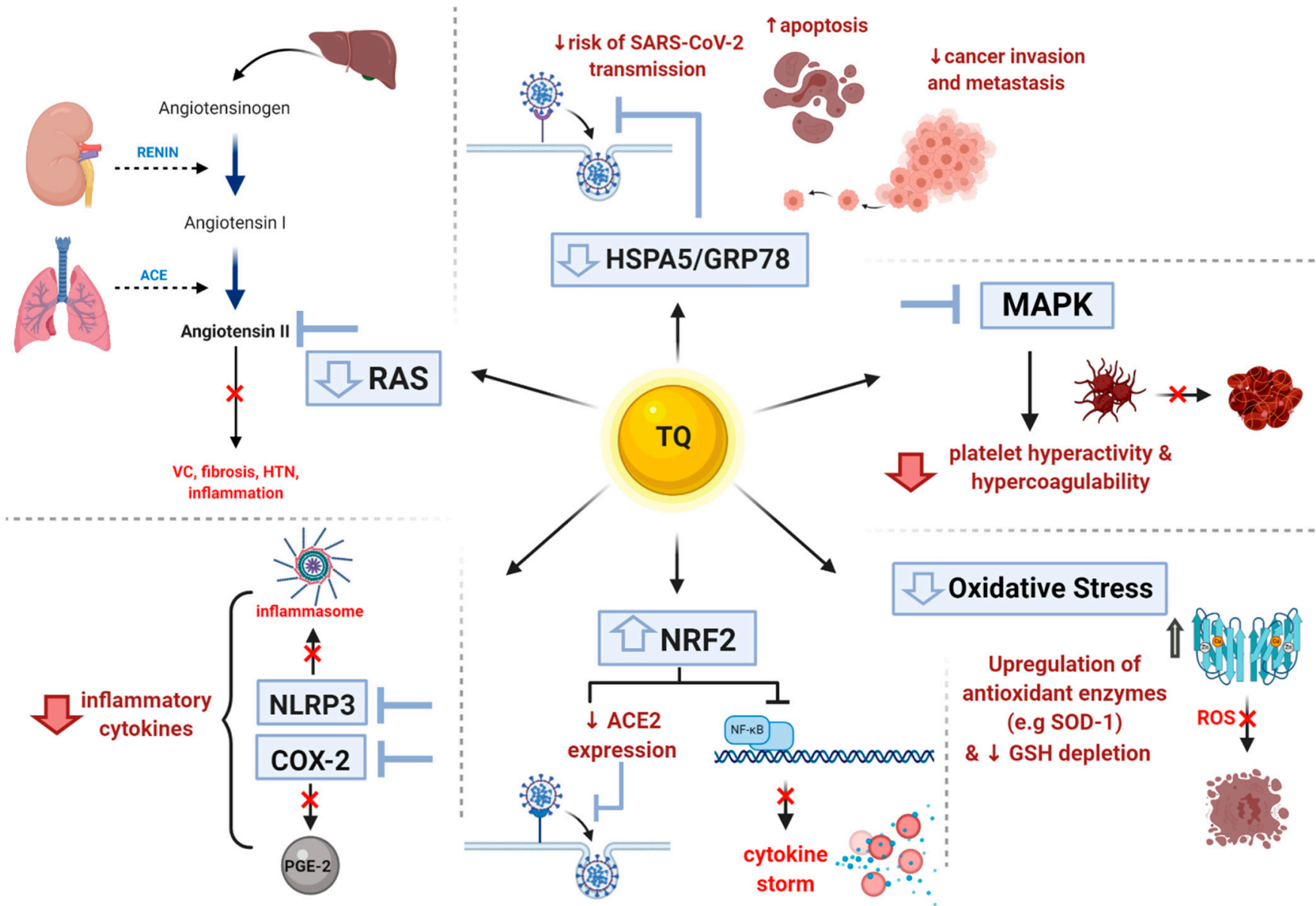

Figure 4. TQ common effects in SARS-CoV-2 infection and cancer. The figure summarizes TQ's actions on molecular targets that cause beneficial outcomes in both SARS-CoV-2 infection and cancer pathogenesis.

1. Increase in Nrf2 that decreases ACE2 expression lessening the viral entry and inhibits NF-kB that downregulates inflammatory genes and cytokine storm beneficial in viral infection and cancer pathogenesis;

2. Reduction in inflammatory cytokines through NLRP3 inhibition, which in turn inhibits inflammasome formation and all inflammasome components and inhibits COX-2 enzyme hence decreasing inflammatory PGE2 levels;

3. Decrease in RAS activity by attenuating angiotensin II levels (ATII) which abolishes its detrimental effects such as vasoconstriction (VC), fibrosis, hypertension (HTN) and inflammation; 
4. Decrease in expression of HSPA5/GRP78, which halts viral entry into the cells and decreases cancer metastasis while enhancing apoptosis.

5. Inhibition of MAPK, which decreases dysregulated platelet activity reducing risks of clotting/coagulopathy.

6. Decrease in oxidative stress by upregulating antioxidant enzymes such as superoxide dismutase (SOD1) and enhancing glutathione (GSH) levels.

Author Contributions: S.E., A.A.E. and N.S.A. contributed toreviewing the literature, writing the review, and designing figures. H.M.E.T. and U.S. were responsible for designing, editing, and revising the review. All authors have read and agreed to the published version of the manuscript.

Funding: This research received no external funding.

Institutional Review Board Statement: Not Applicable.

Data Availability Statement: Not Applicable.

Conflicts of Interest: The authors declare that they have no conflict of interest.

\section{References}

1. Grant, M.C.; Geoghegan, L.; Arbyn, M.; Mohammed, Z.; McGuinness, L.; Clarke, E.L.; Wade, R.G. The prevalence of symptoms in 24,410 adults infected by the novel coronavirus (SARS-CoV-2; COVID-19): A systematic review and meta-analysis of 148 studies from 9 countries. PLoS ONE 2020, 15, e0234765. [CrossRef] [PubMed]

2. Baj, J.; Karakuła-Juchnowicz, H.; Teresiński, G.; Buszewicz, G.; Ciesielka, M.; Sitarz, E.; Forma, A.; Karakuła, K.; Flieger, W.; Portincasa, P.; et al. COVID-19: Specific and Non-Specific Clinical Manifestations and Symptoms: The Current State of Knowledge. J. Clin. Med. 2020, 9, 1753. [CrossRef] [PubMed]

3. Thakkar, S.; Arora, S.; Kumar, A.; Jaswaney, R.; Faisaluddin, M.; Ammad Ud Din, M.; Shariff, M.; Barssoum, K.; Patel, H.P.; Nirav, A.; et al. A Systematic Review of the Cardiovascular Manifestations and Outcomes in the Setting of Coronavirus-19 Disease. Clin. Med. Insights Cardiol. 2020, 14, 1179546820977196. [CrossRef]

4. Chen, X.; Laurent, S.; Onur, O.A.; Kleineberg, N.N.; Fink, G.R.; Schweitzer, F.; Warnke, C.A. systematic review of neurological symptoms and complications of COVID-19. J. Neurol. 2020, 1-11. [CrossRef] [PubMed]

5. Pennisi, M.; Lanza, G.; Falzone, L.; Fisicaro, F.; Ferri, R.; Bella, R. Sars-cov-2 and the nervous system: From clinical features to molecular mechanisms. Int. J. Mol. Sci. 2020, 21, 5475. [CrossRef]

6. Wu, C.P.; Adhi, F.; Highland, K. Recognition and management of respiratory coinfection and secondary bacterial pneumonia in patients with COVID-19. Clevel. Clin. J. Med. 2020, 87, 1-5. [CrossRef]

7. Wiersinga, W.J.; Rhodes, A.; Cheng, A.C.; Peacock, S.J.; Prescott, H.C. Pathophysiology, Transmission, Diagnosis, and Treatment of Coronavirus Disease 2019 (COVID-19): A Review. JAMA J. Am. Med. Assoc. 2020, 324, 782-793. [CrossRef]

8. Jin, Y.H.; Cai, L.; Cheng, Z.S.; Cheng, H.; Deng, T.; Fan, Y.P.; Fang, C.; Huang, D.; Huang, L.Q.; Huang, Q.; et al. A rapid advice guideline for the diagnosis and treatment of 2019 novel coronavirus (2019-nCoV) infected pneumonia (standard version). Mil. Med. Res. 2020, 7, 4. [CrossRef]

9. ElGohary, G.M.; Hashmi, S.; Styczynski, J.; Kharfan-Dabaja, M.A.; Alblooshi, R.M.; de la Cámara, R.; Mohmed, S.; Alshaibani, A.; Cesaro, S.; Abd El-Aziz, N.; et al. The risk and prognosis of COVID-19 infection in cancer patients: A systematic review and meta-analysis. Hematol. Oncol. Stem Cell. Ther. 2020. [CrossRef]

10. Carreira, H.; Strongman, H.; Peppa, M.; McDonald, H.I.; Dos-Santos-Silva, I.; Stanway, S.; Smeeth, L.; Bhaskaran, K. Prevalence of COVID-19-related risk factors and risk of severe influenza outcomes in cancer survivors: A matched cohort study using linked English electronic health records data. EClinicalMedicine 2020, 29-30, 100656. [CrossRef]

11. Vivarelli, S.; Falzone, L.; Torino, F.; Scandurra, G.; Russo, G.; Bordonaro, R.; Pappalardo, F.; Spandidos, D.; Raciti, G.; Libra, M. Immune-checkpoint inhibitors from cancer to COVID-19: A promising avenue for the treatment of patients with COVID-19 (Review). Int. J. Oncol. 2020, 58, 145-157. [CrossRef] [PubMed]

12. Vaninov, N. In the eye of the COVID-19 cytokine storm. Nat. Rev. Immunol. 2020, 20, 277. [CrossRef] [PubMed]

13. Labò, N.; Ohnuki, H.; Tosato, G. Vasculopathy and Coagulopathy Associated with SARS-CoV-2 Infection. Cells 2020, 9, 1583. [CrossRef] [PubMed]

14. Liang, W.; Guan, W.; Chen, R.; Wang, W.; Li, J.; Xu, K.; Li, C.; Ai, Q.; Lu, W.; Liang, H.; et al. Cancer patients in SARS-CoV-2 infection: A nationwide analysis in China. Lancet Oncol. 2020, 21, 335-337. [CrossRef]

15. Wang, H.; Zhang, L. Risk of COVID-19 for patients with cancer. Lancet Oncol. 2020, 21, e181. [CrossRef]

16. Periyanayagam, S.; Arumugam, G.; Ravikumar, A.; Ganesan, V.S. Thymoquinone ameliorates NLRP3-mediated inflammation in the pancreas of albino Wistar rats fed ethanol and high-fat diet. J. Basic Clin. Physiol. Pharmacol. 2015, 26, 623-632. [CrossRef]

17. Guo, L.P.; Liu, S.X.; Yang, Q.; Liu, H.Y.; Xu, L.L.; Hao, Y.H.; Zhang, X.Q. Effect of Thymoquinone on Acute Kidney Injury Induced by Sepsis in BALB/c Mice. BioMed Res. Int. 2020, 2020, 1594726. [CrossRef] 
18. Ghayur, M.N.; Gilani, A.H.; Janssen, L.J. Intestinal, airway, and cardiovascular relaxant activities of thymoquinone. Evid. Based Complement. Altern. Med. 2012, 2012, 305319. [CrossRef]

19. Elbarbry, F.; Ragheb, A.; Marfleet, T.; Shoker, A. Modulation of hepatic drug metabolizing enzymes by dietary doses of thymoquinone in female New Zealand white rabbits. Phyther Res. 2012, 26, 1726-1730. [CrossRef]

20. Ismail, M.; Al-Naqeep, G.; Chan, K.W. Nigella sativa thymoquinone-rich fraction greatly improves plasma antioxidant capacity and expression of antioxidant genes in hypercholesterolemic rats. Free Radic. Biol. Med. 2010, 48, 664-672. [CrossRef]

21. Xu, J.; Zhu, L.; Liu, H.; Li, M.; Liu, Y.; Yang, F.; Pei, Z. Thymoquinone reduces cardiac damage caused by hypercholesterolemia in apolipoprotein E-deficient mice. Lipids Health Dis. 2018, 17, 173. [CrossRef] [PubMed]

22. Yetkin, N.A.; Büyükoğlan, H.; Sönmez, M.F.; Tutar, N.; Gülmez, I.; Yilmaz, I. The protective effects of thymoquinone on lung damage caused by cigarette smoke. Biotech. Histochem. 2020, 95, 268-275. [CrossRef] [PubMed]

23. Nagi, M.N.; Almakki, H.A.; Sayed-Ahmed, M.M.; Al-Bekairi, A.M. Thymoquinone supplementation reverses acetaminopheninduced oxidative stress, nitric oxide production and energy decline in mice liver. Food Chem. Toxicol. 2010, 48, 2361-2365. [CrossRef] [PubMed]

24. Ince, S.; Kucukkurt, I.; Demirel, H.H.; Turkmen, R.; Sever, E. Thymoquinone attenuates cypermethrin induced oxidative stress in Swiss albino mice. Pestic. Biochem. Physiol. 2012, 104, 229-235. [CrossRef]

25. Basarslan, F.; Yilmaz, N.; Ates, S.; Ozgur, T.; Tutanc, M.; Motor, V.K.; Arica, V.; Yilmaz, C.; Inci, M.; Buyukbas, S. Protective effects of thymoquinone on vancomycin-induced nephrotoxicity in rats. Hum. Exp. Toxicol. 2012, 31, 726-733. [CrossRef] [PubMed]

26. Lei, X.; Liu, M.; Yang, Z.; Ji, M.; Guo, X.; Dong, W. Thymoquinone prevents and ameliorates dextran sulfate sodium-induced colitis in mice. Dig. Dis. Sci. 2012, 57, 2296-2303. [CrossRef]

27. Butt, A.S.; Nisar, N.; Mughal, T.A.; Ghani, N.; Altaf, I. Anti-oxidative and anti-proliferative activities of extracted phytochemical compound thymoquinone. J. Pak. Med. Assoc. 2019, 69, 1479-1485. [CrossRef]

28. Hossen, M.J.; Yang, W.S.; Kim, D.; Aravinthan, A.; Kim, J.H.; Cho, J.Y. Thymoquinone: An IRAK1 inhibitor with in vivo and in vitro anti-inflammatory activities. Sci. Rep. 2017, 7, 42995. [CrossRef]

29. Guo, Y.R.; Cao, Q.D.; Hong, Z.S.; Tan, Y.Y.; Chen, S.D.; Jin, H.J.; Tan, K.; Wang, D.Y.; Yan, Y. The origin, transmission and clinical therapies on coronavirus disease 2019 (COVID-19) outbreak—An update on the status. Mil. Med. Res. 2020, 7, 11. [CrossRef]

30. Yan, R.; Zhang, Y.; Li, Y.; Xia, L.; Guo, Y.; Zhou, Q. Structural basis for the recognition of SARS-CoV-2 by full-length human ACE2. Science 2020, 367, 1444-1448. [CrossRef]

31. Loganathan, S.K.; Schleicher, K.; Malik, A.; Quevedo, R.; Langille, E.; Teng, K.; Oh, R.H.; Rathod, B.; Tsai, R.; Samavarchi-Tehrani, P.; et al. Rare driver mutations in head and neck squamous cell carcinomas converge on NOTCH signaling. Science 2020, 367, 1264-1269. [CrossRef] [PubMed]

32. Xu, H.; Zhong, L.; Deng, J.; Peng, J.; Dan, H.; Zeng, X.; Li, T.; Chen, Q. High expression of ACE2 receptor of 2019-nCoV on the epithelial cells of oral mucosa. Int. J. Oral. Sci. 2020, 12, 8. [CrossRef] [PubMed]

33. Perlot, T.; Penninger, J.M. ACE2-From the renin-angiotensin system to gut microbiota and malnutrition. Microbes Infect. 2013, 15, 866-873. [CrossRef] [PubMed]

34. Katopodis, P.; Anikin, V.; Randeva, H.S.; Spandidos, D.A.; Chatha, K.; Kyrou, I.; Karteris, E. Pan-cancer analysis of transmembrane protease serine 2 and cathepsin L that mediate cellular SARS.CoV.2 infection leading to COVID-19. Int. J. Oncol. 2020, 57, 533-539. [CrossRef] [PubMed]

35. Jean, S.S.; Lee, P.I.; Hsueh, P.R. Treatment options for COVID-19: The reality and challenges. J. Microbiol. Immunol. Infect. 2020, 53, 436-443. [CrossRef]

36. Xu, X.; Ong, Y.K.; Wang, D.Y. Role of adjunctive treatment strategies in COVID-19 and a review of international and national clinical guidelines. Mil. Med. Res. 2020, 7, 22. [CrossRef]

37. Isik, A.F.; Kati, I.; Bayram, I.; Ozbek, H. A new agent for treatment of acute respiratory distress syndrome: Thymoquinone. An experimental study in a rat model. Eur. J. Cardio Thorac. Surg. 2005, 28, 301-305. [CrossRef]

38. Ekström, M.; Dahlander, B. Palliativ farmakologisk behandling vid svår covid-19. Lakartidningen 2020, 117, covidwho-68125.

39. Tittarelli, R.; Pellegrini, M.; Scarpellini, M.G.; Marinelli, E.; Bruti, V.; Di Luca, N.M.; Busardò, F.P.; Zaami, S. Hepatotoxicity of paracetamol and related fatalities. Eur. Rev. Med. Pharmacol. Sci. 2017, 21, 95-101.

40. Bjarnason, I. Gastrointestinal safety of NSAIDs and over-the-counter analgesics. Int. J. Clin. Pract. 2013, 67, 37-42. [CrossRef]

41. Hellms, S.; Gueler, F.; Gutberlet, M.; Schebb, N.H.; Rund, K.; Kielstein, J.T.; VoChieu, V.D.; Rauhut, S.; Greite, R.; Martirosian, P.; et al. Single-dose diclofenac in healthy volunteers can cause decrease in renal perfusion measured by functional magnetic resonance imaging. J. Pharm. Pharmacol. 2019, 71, 1262-1270. [CrossRef] [PubMed]

42. Aslan, M.; Kırımlıoğlu, E.; Afşar, E.; Çeker, T.; Yılmaz, Ç. Increased PUFA levels in kidney epithelial cells in the course of diclofenac toxicity. Toxicol. Vitr. 2020, 66, 104836. [CrossRef] [PubMed]

43. Aycan, İ.Ö.; Elpek, Ö.; Akkaya, B.; Kıraç, E.; Tuzcu, H.; Kaya, S.; Coşkunfırat, N.; Aslan, M. Diclofenac induced gastrointestinal and renal toxicity is alleviated by thymoquinone treatment. Food Chem. Toxicol. 2018, 118, 795-804. [CrossRef] [PubMed]

44. Ahmad, S.S.; Najmi, A.K.; Kaundal, M.; Akhtar, M. Gastroprotective Effect of Thymoquinone on Water Immersion Restraint Stress Induced Ulceration in Rats. Drug Res. (Stuttgart) 2017, 67, 366-372. [CrossRef] [PubMed]

45. Magdy, M.A.; Hanan, E.A.; Nabila, E.M. Thymoquinone: Novel gastroprotective mechanisms. Eur. J. Pharmacol. 2012, 697, 126-131. [CrossRef] [PubMed] 
46. Sagit, M.; Korkmaz, F.; Gürgen, S.G.; Kaya, M.; Akcadag, A.; Ozcan, I. The protective role of thymoquinone in the prevention of gentamicin ototoxicity. Am. J. Otolaryngol. Head Neck Med. Surg. 2014, 35, 603-609. [CrossRef]

47. Galaly, S.R.; Ahmed, O.M.; Mahmoud, A.M. Thymoquinone and curcumin prevent gentamicin-induced liver injury by attenuating oxidative stress, inflammation and apoptosis. J. Physiol. Pharmacol. 2014, 65, 823-832.

48. Xiao, J.; Ke, Z.P.; Shi, Y.; Zeng, Q.; Cao, Z. The cardioprotective effect of thymoquinone on ischemia-reperfusion injury in isolated rat heart via regulation of apoptosis and autophagy. J. Cell. Biochem. 2018, 119, 7212-7217. [CrossRef]

49. Kampan, N.C.; Xiang, S.D.; McNally, O.M.; Stephens, A.N.; Quinn, M.A.; Plebanski, M. Immunotherapeutic Interleukin-6 or Interleukin-6 Receptor Blockade in Cancer: Challenges and Opportunities. Curr. Med. Chem. 2017, 25, 4785-4806. [CrossRef]

50. Luo, P.; Liu, Y.; Qiu, L.; Liu, X.; Liu, D.; Li, J. Tocilizumab treatment in COVID-19: A single center experience. J. Med. Virol. 2020, 92, 814-818. [CrossRef]

51. Cobourne-Duval, M.K.; Taka, E.; Mendonca, P.; Soliman, K.F.A. Thymoquinone increases the expression of neuroprotective proteins while decreasing the expression of pro-inflammatory cytokines and the gene expression NFKB pathway signaling targets in LPS/IFN $\gamma$-activated BV-2 microglia cells. J. Neuroimmunol. 2018, 320, 87-97. [CrossRef] [PubMed]

52. Bruce-Hickman, D.; Sajeed, S.M.; Pang, Y.H.; Seow, C.S.; Chen, W.; Gulati Kansal, M. Bowel ulceration following tocilizumab administration in a COVID-19 patient. BMJ Open Gastroenterol. 2020, 7, e000484. [CrossRef] [PubMed]

53. Singh, A.; Ahmad, I.; Akhter, S.; Jain, G.K.; Iqbal, Z.; Talegaonkar, S.; Ahmad, F.J. Nanocarrier based formulation of Thymoquinone improves oral delivery: Stability assessment, in vitro and in vivo studies. Colloids Surf. B Biointerfaces 2013, 102, 822-832. [CrossRef] [PubMed]

54. Uz, U.; Chen, B.; Palmer, J.N.; Cingi, C.; Unlu, H.; Cohen, N. A Effects of thymoquinone and montelukast on sinonasal ciliary beat frequency. Am. J. Rhinol. Allergy 2014, 28, 122-125. [CrossRef] [PubMed]

55. Schneider-Stock, R.; Fakhoury, I.H.; Zaki, A.M.; El-Baba, C.O.; Gali-Muhtasib, H.U. Thymoquinone: Fifty years of success in the battle against cancer models. Drug Discov. Today 2014, 19, 18-30. [CrossRef]

56. Sun, S.Y.; Hail, N.; Lotan, R. Apoptosis as a novel target for cancer chemoprevention. J. Natl. Cancer Inst. 2004, 96, 662-672. [CrossRef]

57. Levine, A.J. P53, the Cellular Gatekeeper for Growth and Division. Cell 1997, 88, 323-331. [CrossRef]

58. Cantley, L.C.; Neel, B.G. New insights into tumor suppression: PTEN suppresses tumor formation by restraining the phosphoinositide 3-kinase/AKT pathway. Proc. Natl. Acad. Sci. USA 1999, 96, 4240-4245. [CrossRef]

59. Reed, J.C. Mechanisms of apoptosis avoidance in cancer. Curr. Opin. Oncol. 1999, 11, 68-75. [CrossRef]

60. Olsson, M.; Zhivotovsky, B. Caspases and cancer. Cell Death Differ. 2011, 18, 1441-1449. [CrossRef]

61. Dastjerdi, M.N.; Mehdiabady, E.M.; Iranpour, F.G.; Bahramian, H. Effect of thymoquinone on P53 gene expression and consequence apoptosis in breast cancer cell line. Int. J. Prev. Med. 2016, 7, 66. [CrossRef] [PubMed]

62. Woo, C.C.; Hsu, A.; Kumar, A.P.; Sethi, G.; Tan, K.H.B. Thymoquinone Inhibits Tumor Growth and Induces Apoptosis in a Breast Cancer Xenograft Mouse Model: The Role of p38 MAPK and ROS. PLoS ONE 2013, 8, e75356. [CrossRef] [PubMed]

63. Woo, C.C.; Loo, S.Y.; Gee, V.; Yap, C.W.; Sethi, G.; Kumar, A.P.; Tan, K.H.B. Anticancer activity of thymoquinone in breast cancer cells: Possible involvement of PPAR- $\gamma$ pathway. Biochem. Pharmacol. 2011, 82, 464-475. [CrossRef] [PubMed]

64. Dehghani, H.; Hashemi, M.; Entezari, M.; Mohsenifar, A. The comparison of anticancer activity of thymoquinone and nanothymoquinone on human breast adenocarcinoma. Iran. J. Pharm Res. 2015, 14, 539-546.

65. Motaghed, M.; Al-Hassan, F.M.; Hamid, S.S. Cellular responses with thymoquinone treatment in human breast cancer cell line MCF-7. Pharmacogn. Res. 2013, 5, 200-206.

66. Linjawi, S.A.A.; Khalil, W.K.B.; Hassanane, M.M.; Ahmed, E.S. Evaluation of the protective effect of Nigella sativa extract and its primary active component thymoquinone against DMBA-induced breast cancer in female rats. Arch. Med. Sci. 2015, 11, 220-229. [CrossRef]

67. Chae, I.G.; Song, N.Y.; Kim, D.H.; Lee, M.Y.; Park, J.M.; Chun, K.S. Thymoquinone induces apoptosis of human renal carcinoma Caki-1 cells by inhibiting JAK2/STAT3 through pro-oxidant effect. Food Chem. Toxicol. 2020, 139, 111253. [CrossRef]

68. Diab-Assaf, M.; Semaan, J.; El-Sabban, M.; Al Jaouni, S.K.; Azar, R.; Kamal, M.A.; Harakeh, S. Inhibition of Proliferation and Induction of Apoptosis by Thymoquinone via Modulation of TGF Family, p53, p21 and Bcl-2 $\alpha$ in Leukemic Cells. Anticancer Agents Med. Chem. 2018, 18, 210-215. [CrossRef]

69. Subburayan, K.; Thayyullathil, F.; Pallichankandy, S.; Rahman, A.; Galadari, S. Par-4-dependent p53 up-regulation plays a critical role in thymoquinone-induced cellular senescence in human malignant glioma cells. Cancer Lett. 2018, 426, 80-97. [CrossRef]

70. Paramasivam, A.; Raghunandhakumar, S.; Priyadharsini, J.V.; Jayaraman, G. In vitro anti-neuroblastoma activity of thymoquinone against neuro-2a cells via cell-cycle arrest. Asian Pac. J. Cancer Prev. 2016, 16, 8313-8319. [CrossRef]

71. Park, J.E.; Kim, D.H.; Ha, E.; Choi, S.M.; Choi, J.S.; Chun, K.S.; Joo, S.H. Thymoquinone induces apoptosis of human epidermoid carcinoma A431 cells through ROS-mediated suppression of STAT3. Chem. Biol. Interact. 2019, 312, 108799. [CrossRef] [PubMed]

72. Ichwan, S.J.A.; Al-Ani, I.M.; Bilal, H.G.; Suriyah, W.H.; Taher, M.; Ikeda, M.A. Apoptotic activities of thymoquinone, an active ingredient of black seed (Nigella sativa), in cervical cancer cell lines. Chin. J. Physiol. 2014, 57, 249-255. [CrossRef] [PubMed]

73. Samarghandian, S.; Azimi-Nezhad, M.; Farkhondeh, T. Thymoquinone-induced antitumor and apoptosis in human lung adenocarcinoma cells. J. Cell. Physiol. 2019, 234, 10421-10431. [CrossRef] [PubMed]

74. Peng, L.; Liu, A.; Shen, Y.; Xu, H.Z.; Yang, S.Z.; Ying, X.Z.; Liao, W.; Liu, H.X.; Lin, Z.Q.; Chen, Q.Y.; et al. Antitumor and anti-angiogenesis effects of thymoquinone on osteosarcoma through the NF-kB pathway. Oncol. Rep. 2013, 29, 571-578. [PubMed] 
75. Connelly, L.; Barham, W.; Onishko, H.M.; Sherrill, T.; Chodosh, L.A.; Blackwell, T.S.; Yull, F.E. Inhibition of NF-kappa B activity in mammary epithelium increases tumor latency and decreases tumor burden. Oncogene 2011, 30, 1402-1412. [CrossRef] [PubMed]

76. Ulasli, S.S.; Celik, S.; Gunay, E.; Ozdemir, M.; Hazman, O.; Ozyurek, A.; Koyuncu, T.; Unlu, M. Anticancer effects of thymoquinone, caffeic acid phenethyl ester and resveratrol on A549 non-small cell lung cancer cells exposed to benzo(a)pyrene. Asian Pac. J. Cancer Prev. 2013, 14, 6159-6164. [CrossRef] [PubMed]

77. Ke, X.; Zhao, Y.; Lu, X.; Wang, Z.; Liu, Y.; Ren, M.; Lu, G.; Zhang, D.; Sun, Z.; Xu, Z.; et al. TQ inhibits hepatocellular carcinoma growth in vitro and in vivo via repression of Notch signaling. Oncotarget 2015, 6, 32610-32621. [CrossRef]

78. Relles, D.; Chipitsyna, G.I.; Gong, Q.; Yeo, C.J.; Arafat, H.A. Thymoquinone Promotes Pancreatic Cancer Cell Death and Reduction of Tumor Size through Combined Inhibition of Histone Deacetylation and Induction of Histone Acetylation. Adv. Prev. Med. 2016, 2016, 1-9. [CrossRef]

79. Paramasivam, A.; Sambantham, S.; Shabnam, J.; Raghunandhakumar, S.; Anandan, B.; Rajiv, R.; Priyadharsini, J.V.; Jayaraman, G. Anti-cancer effects of thymoquinone in mouse neuroblastoma (Neuro-2a) cells through caspase-3 activation with down-regulation of XIAP. Toxicol. Lett. 2012, 213, 151-159. [CrossRef]

80. Xu, D.; Ma, Y.; Zhao, B.; Li, S.; Zhang, Y.; Pan, S.; Wu, Y.; Wang, J.; Wang, D.; Pan, H.; et al. Thymoquinone induces G2/M arrest, inactivates PI3K/Akt and nuclear factor-KB pathways in human cholangiocarcinomas both in vitro and in vivo. Oncol. Rep. 2014, 31, 2063-2070. [CrossRef]

81. Park, E.J.; Chauhan, A.K.; Min, K.J.; Park, D.C.; Kwon, T.K. Thymoquinone induces apoptosis through downregulation of c-FLIP and Bcl-2 in Renal carcinoma Caki cells. Oncol. Rep. 2016, 36, 2261-2267. [CrossRef] [PubMed]

82. Taha, M.M.E.; Sheikh, B.Y.; Salim, L.Z.A.; Mohan, S.; Khan, A.; Kamalidehghan, B.; Ahmadipour, F.; Abdelwahab, S.I. Thymoquinone induces apoptosis and increase ROS in ovarian cancer cell line. Cell. Mol. Biol. 2016, 62, 97-101. [PubMed]

83. Salim, L.Z.A.; Mohan, S.; Othman, R.; Abdelwahab, S.I.; Kamalidehghan, B.; Sheikh, B.Y.; Ibrahim, M.Y. Thymoquinone induces mitochondria-mediated apoptosis in acute lymphoblastic leukaemia in vitro. Molecules 2013, 18, 11219-11240. [CrossRef] [PubMed]

84. Zhang, M.; Du, H.; Huang, Z.; Zhang, P.; Yue, Y.; Wang, W.; Liu, W.; Zeng, J.; Ma, J.; Chen, G.; et al. Thymoquinone induces apoptosis in bladder cancer cell via endoplasmic reticulum stress-dependent mitochondrial pathway. Chem. Biol. Interact. 2018, 292, 65-75. [CrossRef]

85. Elkhoely, A.; Hafez, H.F.; Ashmawy, A.M.; Badary, O.; Abdelaziz, A.; Mostafa, A.; Shouman, S.A. Chemopreventive and therapeutic potentials of thymoquinone in HepG2 cells: Mechanistic perspectives. J. Nat. Med. 2015, 69, 313-323. [PubMed]

86. Das, S.; Dey, K.K.; Dey, G.; Pal, I.; Majumder, A.; MaitiChoudhury, S.; Kundu, S.C.; Mandal, M. Antineoplastic and Apoptotic Potential of Traditional Medicines Thymoquinone and Diosgenin in Squamous Cell Carcinoma. PLoS ONE 2012 , 7, e46641. [CrossRef] [PubMed]

87. Dera, A.; Rajagopalan, P. Thymoquinone attenuates phosphorylation of AKT to inhibit kidney cancer cell proliferation. J. Food Biochem. 2019, 43, e12793. [CrossRef] [PubMed]

88. Hussain, A.R.; Ahmed, M.; Ahmed, S.; Manogaran, P.; Platanias, L.C.; Alvi, S.N.; Al-Kuraya, K.S.; Uddin, S. Thymoquinone suppresses growth and induces apoptosis via generation of reactive oxygen species in primary effusion lymphoma. Free Radic. Biol. Med. 2011, 50, 978-987. [CrossRef] [PubMed]

89. Dergarabetian, E.M.; Ghattass, K.I.; El-Sitt, S.B.; Al Mismar, R.M.; El-Baba, C.O.; Itani, W.S.; Melhem, N.M.; El-Hajj, H.A.; Bazarbachi, A.A.H.; Schneider-Stock, R.; et al. Thymoquinone induces apoptosis in malignant T-cells via generation of ROS. Front. Biosci. Elit. 2013, 5, 706-719. [CrossRef]

90. Krylova, N.G.; Drobysh, M.S.; Semenkova, G.N.; Kulahava, T.A.; Pinchuk, S.V.; Shadyro, O.I. Cytotoxic and antiproliferative effects of thymoquinone on rat C6 glioma cells depend on oxidative stress. Mol. Cell. Biochem. 2019, 462, 195-206. [CrossRef]

91. Liou, Y.F.; Chen, P.N.; Chu, S.C.; Kao, S.H.; Chang, Y.Z.; Hsieh, Y.S.; Chang, H.R. Thymoquinone suppresses the proliferation of renal cell carcinoma cells via reactive oxygen species-induced apoptosis and reduces cell stemness. Environ. Toxicol. 2019, 34, 1208-1220. [CrossRef] [PubMed]

92. Kundu, J.; Choi, B.Y.; Jeong, C.H.; Kundu, J.K.; Chun, K.S. Thymoquinone induces apoptosis in human colon cancer HCT116 cells through inactivation of STAT3 by blocking JAK2- and Src-mediated phosphorylation of EGF receptor tyrosine kinase. Oncol. Rep. 2014, 32, 821-828. [CrossRef] [PubMed]

93. Ashour, A.E.; Ahmed, A.F.; Kumar, A.; Zoheir, K.M.A.; Aboul-Soud, M.A.; Ahmad, S.F.; Attia, S.M.; Abd-Allah, A.R.A.; Cheryan, V.T.; Rishi, A.K. Thymoquinone inhibits growth of human medulloblastoma cells by inducing oxidative stress and caspase-dependent apoptosis while suppressing NF-kB signaling and IL-8 expression. Mol. Cell. Biochem. 2016, 416, 141-155. [CrossRef] [PubMed]

94. Koka, P.S.; Mondal, D.; Schultz, M.; Abdel-Mageed, A.B.; Agrawal, K.C. Studies on molecular mechanisms of growth inhibitory effects of thymoquinone against prostate cancer cells: Role of reactive oxygen species. Exp. Biol. Med. 2010, 235, 751-760. [CrossRef] [PubMed]

95. Bashir, A.O.; El-Mesery, M.E.; Anwer, R.; Eissa, L.A. Thymoquinone potentiates miR-16 and miR-375 expressions in hepatocellular carcinoma. Life Sci. 2020, 254, 117794. [CrossRef]

96. Helmy, S.A.; El-Mesery, M.; El-Karef, A.; Eissa, L.A.; El Gayar, A.M. Thymoquinone upregulates TRAIL/TRAILR2 expression and attenuates hepatocellular carcinoma in vivo model. Life Sci. 2019, 233, 116673. [CrossRef] 
97. Ashour, A.E.; Abd-Allah, A.R.; Korashy, H.M.; Attia, S.M.; Alzahrani, A.Z.; Saquib, Q.; Bakheet, S.A.; Abdel-Hamied, H.E.; Jamal, S.; Rishi, A.K. Thymoquinone suppression of the human hepatocellular carcinoma cell growth involves inhibition of IL-8 expression, elevated levels of TRAIL receptors, oxidative stress and apoptosis. Mol. Cell. Biochem. 2014, 389, 85-98. [CrossRef]

98. Acharya, B.R.; Chatterjee, A.; Ganguli, A.; Bhattacharya, S.; Chakrabarti, G. Thymoquinone inhibits microtubule polymerization by tubulin binding and causes mitotic arrest following apoptosis in A549 cells. Biochimie 2014, 97, 78-91. [CrossRef]

99. Rajput, S.; Kumar, B.N.P.; Dey, K.K.; Pal, I.; Parekh, A.; Mandal, M. Molecular targeting of Akt by thymoquinone promotes G1 arrest through translation inhibition of cyclin D1 and induces apoptosis in breast cancer cells. Life Sci. 2013, 93, 783-790. [CrossRef]

100. Li, F.; Rajendran, P.; Sethi, G. Thymoquinone inhibits proliferation, induces apoptosis and chemosensitizes human multiple myeloma cells through suppression of signal transducer and activator of transcription 3 activation pathway. Br. J. Pharmacol. 2010, 161, 541-554. [CrossRef]

101. Badr, G.; Mohany, M.; Abu-Tarboush, F. Thymoquinone decreases F-actin polymerization and the proliferation of human multiple myeloma cells by suppressing STAT3 phosphorylation and Bcl2/Bcl-XL expression. Lipids Health Dis. 2011, 10, 236. [CrossRef] [PubMed]

102. Attoub, S.; Sperandio, O.; Raza, H.; Arafat, K.; Al-Salam, S.; Al Sultan, M.A.; Al Safi, M.; Takahashi, T.; Adem, A. Thymoquinone as an anticancer agent: Evidence from inhibition of cancer cells viability and invasion in vitro and tumor growth in vivo. Fundam. Clin. Pharmacol. 2013, 27, 557-569. [CrossRef] [PubMed]

103. Ashley, R.E.; Osheroff, N. Natural products as topoisomerase II poisons: Effects of thymoquinone on DNA cleavage mediated by human topoisomerase II $\alpha$. Chem. Res. Toxicol. 2014, 27, 787-793. [CrossRef] [PubMed]

104. Hatiboglu, M.A.; Kocyigit, A.; Guler, E.M.; Akdur, K.; Nalli, A.; Karatas, E.; Tuzgen, S. Thymoquinone Induces Apoptosis in B16-F10 Melanoma Cell Through Inhibition of p-STAT3 and Inhibits Tumor Growth in a Murine Intracerebral Melanoma Model. World Neurosurg. 2018, 114, e182-e190. [CrossRef] [PubMed]

105. El-Baba, C.; Mahadevan, V.; Fahlbusch, F.B.; Suma Mohan, S.; Rau, T.T.; Gali-Muhtasib, H.; Schneider-Stock, R. Thymoquinoneinduced conformational changes of PAK1 interrupt prosurvival MEK-ERK signaling in colorectal cancer. Mol. Cancer 2014, 13, 201. [CrossRef] [PubMed]

106. Rashid, M.; Sanjarin, F.; Sabouni, F. Thymoquinone Effects on Cell Viability, Apoptosis and VEGF-A Gene Expression Level in AGS(CRL-1739) Cell Line. Anticancer Agents Med. Chem. 2019, 19, 820-826. [CrossRef]

107. Ünal, T.D.; Hamurcu, Z.; Delibaşı, N.; Çınar, V.; Güler, A.; Gökçe, S.; Nurdinov, N.; Ozpolat, B. Thymoquinone Inhibits Proliferation and Migration of MDA-MB-231 Triple Negative Breast Cancer Cells by Suppressing Autophagy and Beclin-1 and LC3. Anticancer Agents Med. Chem. 2020, 21, 355-364. [CrossRef]

108. Costa, J.G.; Keser, V.; Jackson, C.; Saraiva, N.; Guerreiro Almeida, N.; Camões, S.P.; Manguinhas, R.; Castro, M.; Miranda, J.P.; Fernandes, A.S.; et al. A multiple endpoint approach reveals potential in vitro anticancer properties of thymoquinone in human renal carcinoma cells. Food Chem. Toxicol. 2020, 136, 111076. [CrossRef]

109. Kabil, N.; Bayraktar, R.; Kahraman, N.; Mokhlis, H.A.; Calin, G.A.; Lopez-Berestein, G.; Ozpolat, B. Thymoquinone inhibits cell proliferation, migration, and invasion by regulating the elongation factor 2 kinase (eEF-2K) signaling axis in triple-negative breast cancer. Breast Cancer Res. Treat. 2018, 171, 593-605. Available online: http://www.ncbi.nlm.nih.gov/pubmed/29971628 (accessed on 11 August 2020). [CrossRef]

110. Kou, B.; Kou, Q.; Ma, B.; Zhang, J.; Sun, B.; Yang, Y.; Li, J.; Zhou, J.; Liu, W. Thymoquinone inhibits metastatic phenotype and epithelial-mesenchymal transition in renal cell carcinoma by regulating the LKB1/AMPK signaling pathway. Oncol. Rep. 2018, 40, 1443-1450. [CrossRef]

111. Feng, L.M.; Wang, X.F.; Huang, Q.X. Thymoquinone induces cytotoxicity and reprogramming of EMT in gastric cancer cells by targeting PI3K/Akt/mTOR pathway. J. Biosci. 2017, 42, 547-554. [CrossRef] [PubMed]

112. Kou, B.; Liu, W.; Zhao, W.; Duan, P.; Yang, Y.; Yi, Q.; Guo, F.; Li, J.; Zhou, J.; Kou, Q. Thymoquinone inhibits epithelialmesenchymal transition in prostate cancer cells by negatively regulating the TGF- $\beta / \mathrm{Smad} 2 / 3$ signaling pathway. Oncol. Rep . 2017, 38, 3592-3598. [CrossRef] [PubMed]

113. Li, J.; Asaduzzaman Khan, M.; Wei, C.; Cheng, J.; Chen, H.; Yang, L.; Ijaz, I.; Fu, J. Thymoquinone inhibits the migration and invasive characteristics of cervical cancer cells siha and caski in vitro by targeting epithelial to mesenchymal transition associated transcription factors twist1 and zeb1. Molecules 2017, 22, 2105. [CrossRef] [PubMed]

114. Ng, W.K.; Yazan, L.S.; Ismail, M. Thymoquinone from Nigella sativa was more potent than cisplatin in eliminating of SiHa cells via apoptosis with down-regulation of Bcl-2 protein. Toxicol. Vitr. 2011, 25, 1392-1398. [CrossRef] [PubMed]

115. Iskender, B.; Izgi, K.; Hizar, E.; Jauch, J.; Arslanhan, A.; Yuksek, E.H.; Canatan, H. Inhibition of epithelial-mesenchymal transition in bladder cancer cells via modulation of mTOR signalling. Tumor Biol. 2016, 37, 8281-8291. [CrossRef] [PubMed]

116. Khan, M.A.; Tania, M.; Wei, C.; Mei, Z.; Fu, S.; Cheng, J.; Xu, J.; Fu, J. Thymoquinone inhibits cancer metastasis by downregulating TWIST1 expression to reduce epithelial to mesenchymal transition. Oncotarget 2015, 6, 19580-19591. [CrossRef] [PubMed]

117. Zhang, Y.; Fan, Y.; Huang, S.; Wang, G.; Han, R.; Lei, F.; Luo, A.; Jing, X.; Zhao, L.; Gu, S.; et al. Thymoquinone inhibits the metastasis of renal cell cancer cells by inducing autophagy via AMPK/mTOR signaling pathway. Cancer Sci. 2018, 109, 3865-3873. [CrossRef]

118. Hussain, A.R.; Uddin, S.; Ahmed, M.; Al-Dayel, F.; Bavi, P.P.; Al-Kuraya, K.S. Phosphorylated IkB $\alpha$ Predicts Poor Prognosis in Activated B-Cell Lymphoma and Its Inhibition with Thymoquinone Induces Apoptosis via ROS Release. PLoS ONE 2013, 8 , e60540. [CrossRef] [PubMed] 
119. Arumugam, P.; Subramanian, R.; Priyadharsini, J.V.; Gopalswamy, J. Thymoquinone inhibits the migration of mouse neuroblastoma (Neuro-2a) cells by down-regulating MMP-2 and MMP-9. Chin. J. Nat. Med. 2016, 14, 904-912. [CrossRef]

120. Liou, Y.F.; Hsieh, Y.S.; Hung, T.W.; Chen, P.N.; Chang, Y.Z.; Kao, S.H.; Lin, S.W.; Chang, H.R. Thymoquinone inhibits metastasis of renal cell carcinoma cell 786-o-si3 associating with downregulation of MMP-2 and u-pa and suppression of PI3K/src signaling. Int. J. Med. Sci. 2019, 16, 686-695. [CrossRef]

121. Chen, M.C.; Lee, N.H.; Hsu, H.H.; Ho, T.J.; Tu, C.C.; Hsieh, D.J.Y.; Lin, Y.M.; Chen, L.M.; Kuo, W.W.; Huang, C.Y. Thymoquinone induces caspase-independent, autophagic cell death in cpt-11-resistant LoVo colon cancer via mitochondrial dysfunction and activation of JNK and p38. J. Agric. Food Chem. 2015, 63, 1540-1546. [CrossRef] [PubMed]

122. Chen, M.C.; Lee, N.H.; Hsu, H.H.; Ho, T.J.; Tu, C.C.; Chen, R.J.; Lin, Y.M.; Viswanadha, V.P.; Kuo, W.W.; Huang, C.Y. Inhibition of NF- $\mathrm{KB}$ and metastasis in irinotecan (CPT-11)-resistant LoVo colon cancer cells by thymoquinone via JNK and p38. Environ. Toxicol. 2017, 32, 669-678. [CrossRef] [PubMed]

123. Ha, J.H.; Jayaraman, M.; Radhakrishnan, R.; Gomathinayagam, R.; Yan, M.; Song, Y.S.; Isidoro, C.; Dhanasekaran, D.N. Differential effects of thymoquinone on lysophosphatidic acid-induced oncogenic pathways in ovarian cancer cells. J. Tradit. Complement. Med. 2020, 10, 207-216. [CrossRef] [PubMed]

124. Shanmugam, M.K.; Ahn, K.S.; Hsu, A.; Woo, C.C.; Yuan, Y.; Tan, K.H.B.; Chinnathambi, A.; Alahmadi, T.A.; Alharbi, S.A.; Koh, A.P.F.; et al. Thymoquinone Inhibits Bone Metastasis of Breast Cancer Cells Through Abrogation of the CXCR4 Signaling Axis. Front. Pharmacol. 2018, 9, 1294. [CrossRef] [PubMed]

125. Badr, G.; Lefevre, E.A.; Mohany, M. Thymoquinone inhibits the CXCL12-induced chemotaxis of multiple myeloma cells and increases their susceptibility to fas-mediated apoptosis. PLoS ONE 2011, 6, e23741. [CrossRef] [PubMed]

126. Zhang, M.; Du, H.; Wang, L.; Yue, Y.; Zhang, P.; Huang, Z.; Lv, W.; Ma, J.; Shao, Q.; Ma, M.; et al. Thymoquinone suppresses invasion and metastasis in bladder cancer cells by reversing EMT through the Wnt/ $\beta$-catenin signaling pathway. Chem. Biol. Interact. 2020, 320, 109022. [CrossRef] [PubMed]

127. Kolli-Bouhafs, K.; Boukhari, A.; Abusnina, A.; Velot, E.; Gies, J.P.; Lugnier, C.; Rondé, P. Thymoquinone reduces migration and invasion of human glioblastoma cells associated with FAK, MMP-2 and MMP-9 down-regulation. Investig. New Drugs. 2012, 30, 2121-2131. [CrossRef]

128. Yang, J.; Kuang, X.R.; Lv, P.T.; Yan, X.X. Thymoquinone inhibits proliferation and invasion of human nonsmall-cell lung cancer cells via ERK pathway. Tumor Biol. 2014, 36, 259-269. [CrossRef]

129. Zhu, W.Q.; Wang, J.; Guo, X.F.; Liu, Z.; Dong, W.G. Thymoquinone inhibits proliferation in gastric cancer via the STAT3 pathway in vivo and in vitro. World J. Gastroenterol. 2016, 22, 4149-4159. [CrossRef]

130. Hsu, H.H.; Chen, M.C.; Day, C.H.; Lin, Y.M.; Li, S.Y.; Tu, C.C.; Padma, V.V.; Shih, H.N.; Kuo, W.W.; Huang, C.Y. Thymoquinone suppresses migration of LoVo human colon cancer cells by reducing prostaglandin E2 induced COX-2 activation. World J. Gastroenterol. 2017, 23, 1171-1179. [CrossRef]

131. Lang, M.; Borgmann, M.; Oberhuber, G.; Evstatiev, R.; Jimenez, K.; Dammann, K.W.; Jambrich, M.; Khare, V.; Campregher, C.; Ristl, R.; et al. Thymoquinone attenuates tumor growth in ApcMin mice by interference with Wnt-signaling. Mol. Cancer 2013, 12, 41. [CrossRef] [PubMed]

132. Ren, X.; Luo, W. Exploration of pro-apoptotic effect of Thymoquinone on oral squamous cell carcinoma cells through PI3K/Akt signaling pathway. Cell. Mol. Biol. 2019, 65, 61-64. [CrossRef] [PubMed]

133. Sakalar, C.; Yuruk, M.; Kaya, T.; Aytekin, M.; Kuk, S.; Canatan, H. Pronounced transcriptional regulation of apoptotic and TNF-NF-kappa-B signaling genes during the course of thymoquinone mediated apoptosis in HeLa cells. Mol. Cell. Biochem. 2013, 383, 243-251. [CrossRef] [PubMed]

134. Ahmad, I.; Muneer, K.M.; Tamimi, I.A.; Chang, M.E.; Ata, M.O.; Yusuf, N. Thymoquinone suppresses metastasis of melanoma cells by inhibition of NLRP3 inflammasome. Toxicol. Appl. Pharmacol. 2013, 270, 70-76. [CrossRef] [PubMed]

135. Kotowski, U.; Heiduschka, G.; Kadletz, L.; Fahim, T.; Seemann, R.; Schmid, R.; Schneider, S.; Mitterbauer, A.; Thurnher, D. Effect of thymoquinone on head and neck squamous cell carcinoma cells in vitro: Synergism with radiation. Oncol. Lett. 2017, 14, 1147-1151. [CrossRef]

136. Rajput, S.; Kumar, B.N.P.; Banik, P.; Parida, S.; Mandal, M. Thymoquinone restores radiation-induced TGF- $\beta$ expression and abrogates EMT in chemoradiotherapy of breast cancer cells. J. Cell. Physiol. 2015, 230, 620-629. [CrossRef]

137. Velho-Pereira, R.; Kumar, A.; Pandey, B.N.; Jagtap, A.G.; Mishra, K.P. Radiosensitization in human breast carcinoma cells by thymoquinone: Role of cell cycle and apoptosis. Cell. Biol. Int. 2011, 35, 1025-1029. [CrossRef]

138. Farooqui, Z.; Shahid, F.; Khan, A.A.; Khan, F. Oral administration of Nigella sativa oil and thymoquinone attenuates long term cisplatin treatment induced toxicity and oxidative damage in rat kidney. Biomed. Pharmacother. 2017, 96, 912-923. [CrossRef]

139. Al-Malki, A.L.; Sayed, A.A.R. Thymoquinone attenuates cisplatin-induced hepatotoxicity via nuclear factor kappa- $\beta$. BMC Complement. Altern. Med. 2014, 14, 282. [CrossRef]

140. Liu, X.; Dong, J.; Cai, W.; Pan, Y.; Li, R.; Li, B. The effect of thymoquinone on apoptosis of SK-OV-3 ovarian cancer cell by regulation of Bcl-2 and Bax. Int. J. Gynecol. Cancer 2017, 27, 1596-1601. [CrossRef]

141. Wilson, A.J.; Saskowski, J.; Barham, W.; Yull, F.; Khabele, D. Thymoquinone enhances cisplatin-response through direct tumor effects in a syngeneic mouse model of ovarian cancer. J. Ovarian Res. 2015, 8, 46. [CrossRef] [PubMed]

142. Albassam, A.A.; Ahad, A.; Alsultan, A.; Al-Jenoobi, F.I. Inhibition of cytochrome P450 enzymes by thymoquinone in human liver microsomes. Saud. Pharm J. 2018, 26, 673-677. [CrossRef] [PubMed] 
143. Bashmail, H.A.; Alamoudi, A.A.; Noorwali, A.; Hegazy, G.A.; Ajabnoor, G.M.; Al-Abd, A.M. Thymoquinone enhances paclitaxel anti-breast cancer activity via inhibiting tumor-associated stem cells despite apparent mathematical antagonism. Molecules 2020, 25, 426. [CrossRef] [PubMed]

144. Singh, S.K.; Apata, T.; Gordetsky, J.B.; Singh, R. Docetaxel combined with thymoquinone induces apoptosis in prostate cancer cells via inhibition of the PI3K/AKT signaling pathway. Cancers 2019, 11, 1390. [CrossRef]

145. Dirican, A.; Atmaca, H.; Bozkurt, E.; Erten, C.; Karaca, B.; Uslu, R. Novel combination of docetaxel and thymoquinone induces synergistic cytotoxicity and apoptosis in DU-145 human prostate cancer cells by modulating PI3K-AKT pathway. Clin. Transl. Oncol. 2014, 17, 145-151. [CrossRef]

146. Arafa, E.S.A.; Zhu, Q.; Shah, Z.I.; Wani, G.; Barakat, B.M.; Racoma, I.; El-Mahdy, M.A.; Wani, A.A. Thymoquinone up-regulates PTEN expression and induces apoptosis in doxorubicin-resistant human breast cancer cells. Mutat. Res. Fundam. Mol. Mech. Mutagen. 2011, 706, 28-35. [CrossRef]

147. Effenberger-Neidnicht, K.; Schobert, R. Combinatorial effects of thymoquinone on the anti-cancer activity of doxorubicin. Cancer Chemother. Pharmacol. 2011, 67, 867-874. [CrossRef]

148. Fatfat, M.; Fakhoury, I.; Habli, Z.; Mismar, R.; Gali-Muhtasib, H. Thymoquinone enhances the anticancer activity of doxorubicin against adult T-cell leukemia in vitro and in vivo through ROS-dependent mechanisms. Life Sci. 2019, 232, 116628. [CrossRef]

149. Brown, R.K.; Wilson, G.; Tucci, M.; Benghuzzi, H. The effects of thymoquinone and doxorubicin on leukemia and cardiomyocyte cell lines. Biomed. Sci. Instrum. 2014, 50, 391-396.

150. Soltani, A.; Pourgheysari, B.; Shirzad, H.; Sourani, Z. Antiproliferative and Apoptosis-Inducing Activities of Thymoquinone in Lymphoblastic Leukemia Cell Line. Indian J. Hematol. Blood Transfus. 2017, 33, 516-524. [CrossRef]

151. Ganji-Harsini, S.; Khazaei, M.; Rashidi, Z.; Ghanbari, A. Thymoquinone could increase the efficacy of tamoxifen induced apoptosis in human breast cancer cells: An in vitro study. Cell J. 2016, 18, 245-254. [PubMed]

152. Rajput, S.; Kumar, B.N.P.; Sarkar, S.; Das, S.; Azab, B.; Santhekadur, P.K.; Das, S.K.; Emdad, L.; Sarkar, D.; Fisher, P.B.; et al. Targeted Apoptotic Effects of Thymoquinone and Tamoxifen on XIAP Mediated Akt Regulation in Breast Cancer. PLoS ONE 2013, 8, e61342. [CrossRef]

153. Suddek, G.M. Protective role of thymoquinone against liver damage induced by tamoxifen in female rats. Can. J. Physiol. Pharmacol. 2014, 92, 640-644. [CrossRef] [PubMed]

154. Ndreshkjana, B.; Çapci, A.; Klein, V.; Chanvorachote, P.; Muenzner, J.K.; Huebner, K.; Steinmann, S.; Erlenbach-Wuensch, K.; Geppert, C.I.; Agaimy, A.; et al. Combination of 5-fluorouracil and thymoquinone targets stem cell gene signature in colorectal cancer cells. Cell Death Dis. 2019, 10, 379. [CrossRef] [PubMed]

155. Kensara, O.A.; El-Shemi, A.G.; Mohamed, A.M.; Refaat, B.; Idris, S.; Ahmad, J. Thymoquinone subdues tumor growth and potentiates the chemopreventive effect of 5-fluorouracil on the early stages of colorectal carcinogenesis in rats. Drug Des. Dev. Ther. 2016, 10, 2239-2253.

156. Lei, X.; Lv, X.; Liu, M.; Yang, Z.; Ji, M.; Guo, X.; Dong, W. Thymoquinone inhibits growth and augments 5-fluorouracil-induced apoptosis in gastric cancer cells both in vitro and in vivo. Biochem. Biophys. Res. Commun. 2012, 417, 864-868. [CrossRef]

157. Abuzinadah, M.F.; Ahmad, A. Pharmacological studies on the efficacy of a thymoquinone-containing novel polyherbal formulation against cisplatin-induced hepatorenal toxicity in rats. J. Food Biochem. 2020, 44, e13131. [CrossRef] [PubMed]

158. Hu, X.; Ma, J.; Vikash, V.; Li, J.; Wu, D.; Liu, Y.; Zhang, J.; Dong, W. Thymoquinone Augments Cisplatin-Induced Apoptosis on Esophageal Carcinoma Through Mitigating the Activation of JAK2/STAT3 Pathway. Dig. Dis. Sci. 2018, 63, 126-134. [CrossRef]

159. Ma, J.; Hu, X.; Li, J.; Wu, D.; Lan, Q.; Wang, Q.; Tian, S.; Dong, W. Enhancing conventional chemotherapy drug cisplatin-induced anti-tumor effects on human gastric cancer cells both in vitro and in vivo by Thymoquinone targeting PTEN gene. Oncotarget 2017, 8, 85926-85939. [CrossRef] [PubMed]

160. Alaufi, O.M.; Noorwali, A.; Zahran, F.; Al-Abd, A.M.; Al-Attas, S. Cytotoxicity of thymoquinone alone or in combination with cisplatin (CDDP) against oral squamous cell carcinoma in vitro. Sci. Rep. 2017, 7, 13131. [CrossRef]

161. Kadil, Y.; Mouhcine, M.; Filali, H. In Silico Investigation of the SARS CoV2 Protease with Thymoquinone Major Constituent of Nigella Sativa. Curr. Drug. Discov. Technol. 2020, 17. [CrossRef] [PubMed]

162. Ibrahim, I.M.; Abdelmalek, D.H.; Elfiky, A.A. GRP78: A cell's response to stress. Life Sci. 2019, 226, 156-163. [CrossRef] [PubMed]

163. Ibrahim, I.M.; Abdelmalek, D.H.; Elshahat, M.E.; Elfiky, A.A. COVID-19 spike-host cell receptor GRP78 binding site prediction. J. Infect. 2020, 80, 554-562. [CrossRef] [PubMed]

164. Aguiar, J.; Tremblay, B.J.-M.; Mansfield, M.; Woody, O.; Lobb, B.; Banerjee, A.; Chandiramohan, A.; Tiessen, N.; Dvorkin-Gheva, A.; Revill, S.; et al. Gene expression and in situ protein profiling of candidate SARS-CoV-2 receptors in human airway epithelial cells and lung tissue. Eur. Respir. J. 2020, 56, 2001123. [CrossRef] [PubMed]

165. Köseler, A.; Sabirli, R.; Gören, T.; Türkçüer, I.; Kurt, Ö. Endoplasmic reticulum stress markers in SARS-COV-2 infection and pneumonia: Case-control study. In Vivo (Brooklyn) 2020, 34, 1645-1650.

166. Xie, J.; Tao, Z.-H.; Zhao, J.; Li, T.; Wu, Z.-H.; Zhang, J.-F.; Zhang, J.; Hu, X.-C. Glucose regulated protein 78 (GRP78) inhibits apoptosis and attentinutes chemosensitivity of gemcitabine in breast cancer cell via AKT/mitochondrial apoptotic pathway. Biochem. Biophys. Res. Commun. 2016, 474, 612-619. [CrossRef]

167. Kuroda, K.; Horiguchi, A.; Asano, T.; Ito, K.; Asakuma, J.; Sato, A.; Yoshii, H.; Hayakawa, M.; Sumitomo, M.; Asano, T. Glucose-regulated protein 78 positivity as a predictor of poor survival in patients with renal cell carcinoma. Urol. Int. 2011, 87, 450-456. [CrossRef] 
168. Teng, Y.; Ai, Z.; Wang, Y.; Wang, J.; Luo, L. Proteomic identification of PKM2 and HSPA5 as potential biomarkers for predicting high-risk endometrial carcinoma. J. Obstet. Gynaecol. Res. 2013, 39, 317-325. [CrossRef]

169. Zhang, J.; Jiang, Y.; Jia, Z.; Li, Q.; Gong, W.; Wang, L.; Wei, D.; Yao, J.; Fang, S.; Xie, K. Association of elevated GRP78 expression with increased lymph node metastasis and poor prognosis in patients with gastric cancer. Clin. Exp. Metastasis 2006, 23, 401-410. [CrossRef]

170. Xing, X.; Lai, M.; Wang, Y.; Xu, E.; Huang, Q. Overexpression of glucose-regulated protein 78 in colon cancer. Clin. Chim Acta 2006, 364, 308-315. [CrossRef]

171. Wu, C.T.; Wang, W.C.; Chen, M.F.; Su, H.Y.; Chen, W.Y.; Wu, C.H.; Chang, Y.J.; Liu, H.H. Glucose-regulated protein 78 mediates hormone-independent prostate cancer progression and metastasis through maspin and COX-2 expression. Tumor Biol. 2014, 35, 195-204. [CrossRef] [PubMed]

172. Bouhlel, A.; Mosbah, B.; Abdallah, H.; Ribault, C.; Viel, R.; Mannaï, S.; Corlu, A.; Abdennebi, B. Thymoquinone prevents endoplasmic reticulum stress and mitochondria-induced apoptosis in a rat model of partial hepatic warm ischemia reperfusion. Biomed. Pharmacother. 2017, 94, 964-973. [CrossRef] [PubMed]

173. Elfiky, A.A. Natural products may interfere with SARS-CoV-2 attachment to the host cell. J. Biomol. Struct. Dyn. 2020, 1-16. [CrossRef]

174. O'Connell, M.A.; Hayes, J.D. The Keap1/Nrf2 pathway in health and disease: From the bench to the clinic. Biochem. Soc. Trans. 2015, 43, 687-689. [CrossRef]

175. Su, C.; Zhang, P.; Song, X.; Shi, Q.; Fu, J.; Xia, X.; Bai, H.; Hu, L.; Xu, D.; Song, E.; et al. Tetrachlorobenzoquinone activates NRF2 signaling by keap1 cross-linking and ubiquitin translocation but not keap1-cullin3 complex dissociation. Chem. Res. Toxicol. 2015, 28, 765-774. [CrossRef]

176. Lewis, K.N.; Mele, J.; Hayes, J.D.; Buffenstein, R. Nrf2, a guardian of healthspan and gatekeeper of species longevity. Integr. Comp. Biol. 2010, 50, 829-843. [CrossRef]

177. Niture, S.K.; Kaspar, J.W.; Shen, J.; Jaiswal, A.K. Nrf2 signaling and cell survival. Toxicol. Appl. Pharmacol. 2010, 244, 37-42. [CrossRef]

178. Das, B.N.; Kim, Y.W.; Keum, Y.S. Mechanisms of Nrf2/keap1-dependent phase II cytoprotective and detoxifying gene expression and potential cellular targets of chemopreventive isothiocyanates. Oxid. Med. Cell. Longev. 2013, 2013, 839409. [CrossRef]

179. Prawan, A.; Kundu, J.K.; Surh, Y.J. Molecular basis of heme oxygenase-1 induction: Implications for chemoprevention and chemoprotection. Antioxid. Redox Signal. 2005, 7, 1688-1703. [CrossRef]

180. Denicola, G.M.; Karreth, F.A.; Humpton, T.J.; Gopinathan, A.; Wei, C.; Frese, K.; Mangal, D.; Yu, K.H.; Yeo, C.J.; Calhoun, E.S.; et al. Oncogene-induced Nrf2 transcription promotes ROS detoxification and tumorigenesis. Nature 2011, 475, 106-110. [CrossRef]

181. Satoh, H.; Moriguchi, T.; Takai, J.; Ebina, M.; Yamamoto, M. Nrf2 prevents initiation but accelerates progression through the kras signaling pathway during lung carcinogenesis. Cancer Res. 2013, 73, 4158-4168. [CrossRef] [PubMed]

182. Tao, S.; Rojo de la Vega, M.; Chapman, E.; Ooi, A.; Zhang, D.D. The effects of NRF2 modulation on the initiation and progression of chemically and genetically induced lung cancer. Mol. Carcinog. 2018, 57, 182-192. [CrossRef] [PubMed]

183. Rojo de la Vega, M.; Chapman, E.; Zhang, D.D. NRF2 and the Hallmarks of Cancer. Cancer Cell 2018, $34,21-43$. [CrossRef] [PubMed]

184. Kobayashi, E.H.; Suzuki, T.; Funayama, R.; Nagashima, T.; Hayashi, M.; Sekine, H.; Tanaka, N.; Moriguchi, T.; Motohashi, H.; Nakayama, K.; et al. Nrf2 suppresses macrophage inflammatory response by blocking proinflammatory cytokine transcription. Nat. Commun. 2016, 7, 11624. [CrossRef] [PubMed]

185. Singh, N.; Saha, L.; Kumari, P.; Singh, J.; Bhatia, A.; Banerjee, D.; Chakrabarti, A. Effect of dimethyl fumarate on neuroinflammation and apoptosis in pentylenetetrazol kindling model in rats. Brain Res. Bull. 2019, 144, 233-245. [CrossRef]

186. Battino, M.; Giampieri, F.; Pistollato, F.; Sureda, A.; de Oliveira, M.R.; Pittalà, V.; Fallarino, F.; Nabavi, S.F.; Atanasov, A.G.; Nabavi, S.M. Nrf2 as regulator of innate immunity: A molecular Swiss army knife! Biotechnol. Adv. 2018, 36, 358-370. [CrossRef] [PubMed]

187. Chhunchha, B.; Kubo, E.; Singh, D.P. Sulforaphane-Induced Klf9/Prdx6 Axis Acts as a Molecular Switch to Control Redox Signaling and Determines Fate of Cells. Cells 2019, 8, 1159. [CrossRef]

188. Zucker, S.N.; Fink, E.E.; Bagati, A.; Mannava, S.; Bianchi-Smiraglia, A.; Bogner, P.N.; Wawrzyniak, J.A.; Foley, C.; Leonova, K.I.; Grimm, M.J.; et al. Nrf2 amplifies oxidative stress via induction of Klf9. Mol. Cell. 2014, 53, 916-928. [CrossRef]

189. Lee, C. Therapeutic modulation of virus-induced oxidative stress via the Nrf2-dependent antioxidative pathway. Oxid. Med. Cell. Longev. 2018, 2018, 6208067. [CrossRef]

190. Lomeli, N.; Bota, D.A.; Davies, K.J.A. Diminished stress resistance and defective adaptive homeostasis in age-related diseases. Clin. Sci. 2017, 131, 2573-2599. [CrossRef]

191. Zhao, S.; Ghosh, A.; Lo, C.S.; Chenier, I.; Scholey, J.W.; Filep, J.G.; Ingelfinger, J.R.; Zhang, S.L.; Chan, J.S.D. Nrf2 deficiency upregulates intrarenal angiotensin-converting enzyme-2 and angiotensin 1-7 receptor expression and attenuates hypertension and nephropathy in diabetic mice. Endocrinology 2018, 159, 836-852. [CrossRef] [PubMed]

192. McCord, J.M.; Hybertson, B.M.; Cota-Gomez, A.; Geraci, K.P.; Gao, B. Nrf2 activator pb125 ${ }^{\circledR}$ as a potential therapeutic agent against covid-19. Antioxidants 2020, 9, 518. [CrossRef] [PubMed]

193. Hassan, S.M.; Jawad, M.J.; Ahjel, S.W.; Singh, R.B.; Singh, J.; Awad, S.M.; Hadi, N.R. The Nrf2 Activator (DMF) and Covid-19: Is there a Possible Role? Med. Arch. (Sarajevo) 2020, 74, 134-138. [CrossRef] [PubMed] 
194. Ramos-Gomez, M.; Kwak, M.K.; Dolan, P.M.; Itoh, K.; Yamamoto, M.; Talalay, P.; Kensler, T.W. Sensitivity to carcinogenesis is increased and chemoprotective efficacy of enzyme inducers is lost in nrf2 transcription factor-deficient mice. Proc. Natl. Acad. Sci. USA 2001, 98, 3410-3415. [CrossRef] [PubMed]

195. Bauer, A.K.; Cho, H.Y.; Miller-DeGraff, L.; Walker, C.; Helms, K.; Fostel, J.; Yamamoto, M.; Kleeberger, S.R. Targeted deletion of Nrf2 reduces urethane-induced lung tumor development in mice. PLoS ONE 2011, 6, e26590. [CrossRef]

196. Long, M.; Tao, S.; De La Vega, M.R.; Jiang, T.; Wen, Q.; Park, S.L.; Zhang, D.D.; Wondrak, G.T. Nrf2-dependent suppression of azoxymethane/dextran sulfate sodium-induced colon carcinogenesis by the cinnamon-derived dietary factor cinnamaldehyde. Cancer Prev. Res. 2015, 8, 444-454. [CrossRef]

197. Shen, T.; Jiang, T.; Long, M.; Chen, J.; Ren, D.M.; Wong, P.K.; Chapman, E.; Zhou, B.; Zhang, D.D. A Curcumin Derivative That Inhibits Vinyl Carbamate-Induced Lung Carcinogenesis via Activation of the Nrf2 Protective Response. Antioxid. Redox Signal. 2015, 23, 651-664. [CrossRef]

198. Sekhar, K.R.; Freeman, M.L. Nrf2 promotes survival following exposure to ionizing radiation. Free Radic. Biol. Med. 2015, 88, 268-274. [CrossRef]

199. Tao, S.; Justiniano, R.; Zhang, D.D.; Wondrak, G.T. The Nrf2-inducers tanshinone I and dihydrotanshinone protect human skin cells and reconstructed human skin against solar simulated UV. Redox Biol. 2013, 1, 532-541. [CrossRef]

200. Tao, S.; Park, S.L.; De La Vega, M.R.; Zhang, D.D.; Wondrak, G.T. Systemic administration of the apocarotenoid bixin protects skin against solar UV-induced damage through activation of NRF2. Free Radic. Biol. Med. 2015, 89, 690-700. [CrossRef]

201. Knatko, E.V.; Ibbotson, S.H.; Zhang, Y.; Higgins, M.; Fahey, J.W.; Talalay, P.; Dawe, R.S.; Ferguson, J.; Huang, J.T.J.; Clarke, R.; et al. Nrf2 activation protects against solar-simulated ultraviolet radiation in mice and humans. Cancer Prev. Res. 2015, 8, 475-486. [CrossRef] [PubMed]

202. Wang, H.; Liu, X.; Long, M.; Huang, Y.; Zhang, L.; Zhang, R.; Zheng, Y.; Liao, X.; Wang, Y.; Liao, Q.; et al. NRF2 activation by antioxidant antidiabetic agents accelerates tumor metastasis. Sci. Transl. Med. 2016, 8, 334ra51. [CrossRef] [PubMed]

203. Hanahan, D.; Weinberg, R.A. Hallmarks of cancer: The next generation. Cell 2011, 144, 646-674. [PubMed]

204. Kundu, J.; Kim, D.H.; Kundu, J.K.; Chun, K.S. Thymoquinone induces heme oxygenase-1 expression in HaCaT cells via Nrf2/ARE activation: Akt and AMPK $\alpha$ as upstream targets. Food Chem. Toxicol. 2014, 65, 18-26. [CrossRef] [PubMed]

205. Velagapudi, R.; Kumar, A.; Bhatia, H.S.; El-Bakoush, A.; Lepiarz, I.; Fiebich, B.L.; Olajide, O.A. Inhibition of neuroinflammation by thymoquinone requires activation of Nrf2/ARE signalling. Int. Immunopharmacol. 2017, 48, 17-29. [CrossRef]

206. Ye, Q.; Wang, B.; Mao, J. The pathogenesis and treatment of the 'Cytokine Storm" in COVID-19. J. Infect. 2020, 80, 607-613. [CrossRef]

207. Cheng, J.L.; Huang, C.; Zhang, G.J.; Liu, D.W.; Li, P.; Lu, C.Y.; Li, J. Epidemiological characteristics of novel coronavirus pneumonia in Henan. Zhonghua Jie He He Hu Xi Za Zhi 2020, 43, 327-331.

208. Li, Y.C.; Bai, W.Z.; Hashikawa, T. The neuroinvasive potential of SARS-CoV2 may play a role in the respiratory failure of COVID-19 patients. J. Med. Virol. 2020, 92, 552-555. [CrossRef]

209. Liu, H.; Sun, Y.; Zhang, Y.; Yang, G.; Guo, L.; Zhao, Y.; Pei, Z. Role of Thymoquinone in Cardiac Damage Caused by Sepsis from BALB/c Mice. Inflammation 2019, 42, 516-525. [CrossRef]

210. Pei, Z.; Hu, J.; Bai, Q.; Liu, B.; Cheng, D.; Liu, H.; Na, R.; Yu, Q. Thymoquinone protects against cardiac damage from doxorubicin-induced heart failure in Sprague-Dawley rats. RSC Adv. 2018, 8, 14633-14639. [CrossRef]

211. Nagi, M.N.; Al-Shabanah, O.A.; Hafez, M.M.; Sayed-Ahmed, M.M. Thymoquinone supplementation attenuates cyclophosphamideinduced cardiotoxicity in rats. J. Biochem. Mol. Toxicol. 2011, 25, 135-142. [CrossRef] [PubMed]

212. Nemmar, A.; Al-Salam, S.; Zia, S.; Marzouqi, F.; Al-Dhaheri, A.; Subramaniyan, D.; Dhanasekaran, S.; Yasin, J.; Ali, B.H.; Kazzam, E.E. Contrasting actions of diesel exhaust particles on the pulmonary and cardiovascular systems and the effects of thymoquinone. Br. J. Pharmacol. 2011, 164, 1871-1882. [CrossRef] [PubMed]

213. Çolak, M.; Kalemci, S.; Alpaydın, A.Ö.; Karaçam, V.; Meteoğlu, I.; Yılmaz, O.; Itil, B.O. Efficacy of thymoquinone in the treatment of experimental lipopolysaccharide-induced acute lung injury. Kardiochir. Torakochir. Pol. 2020, 17, 65-69. [CrossRef] [PubMed]

214. Pourgholamhossein, F.; Sharififar, F.; Rasooli, R.; Pourgholi, L.; Nakhaeipour, F.; Samareh-Fekri, H.; Iranpour, M.; Mandegary, A. Thymoquinone effectively alleviates lung fibrosis induced by paraquat herbicide through down-regulation of pro-fibrotic genes and inhibition of oxidative stress. Environ. Toxicol. Pharmacol. 2016, 45, 340-345. [CrossRef]

215. Keyhanmanesh, R.; Pejman, L.; Omrani, H.; Mirzamohammadi, Z.; Shahbazfar, A.A. The effect of single dose of thymoquinone, the main constituents of Nigella sativa, in guinea pig model of asthma. BioImpacts 2014, 4, 75-81.

216. El-Khouly, D.; El-Bakly, W.M.; Awad, A.S.; El-Mesallamy, H.O.; El-Demerdash, E. Thymoquinone blocks lung injury and fibrosis by attenuating bleomycin-induced oxidative stress and activation of nuclear factor Kappa-B in rats. Toxicology 2012, 302, 106-113. [CrossRef]

217. Zhu, N.; Zhao, X.; Xiang, Y.; Ye, S.; Huang, J.; Hu, W.; Lv, L.; Zeng, C. Thymoquinone attenuates monocrotaline-induced pulmonary artery hypertension via inhibiting pulmonary arterial remodeling in rats. Int. J. Cardiol. 2016, 221, 587-596. [CrossRef]

218. Kanter, M. Thymoquinone attenuates lung injury induced by chronic toluene exposure in rats. Toxicol. Ind. Health 2011, 27, 387-395. [CrossRef]

219. Suddek, G.M.; Ashry, N.A.; Gameil, N.M. Thymoquinone attenuates cyclophosphamide-induced pulmonary injury in rats. Inflammopharmacology 2013, 21, 427-435.

220. Suddek, G.M. Thymoquinone-induced relaxation of isolated rat pulmonary artery. J. Ethnopharmacol. 2010, 127, 210-214. [CrossRef] 
221. Ammar, E.S.M.; Gameil, N.M.; Shawky, N.M.; Nader, M.A. Comparative evaluation of anti-inflammatory properties of thymoquinone and curcumin using an asthmatic murine model. Int. Immunopharmacol. 2011, 11, 2232-2236. [CrossRef] [PubMed]

222. Su, X.; Ren, Y.; Yu, N.; Kong, L.; Kang, J. Thymoquinone inhibits inflammation, neoangiogenesis and vascular remodeling in asthma mice. Int. Immunopharmacol. 2016, 38, 70-80. [CrossRef] [PubMed]

223. Kalemci, S.; Micili, S.C.; Acar, T.; Senol, T.; Dirican, N.; Omeroglu, G.; Bagriyanik, A.; Kamaci, G.; Yilmaz, O. Effectiveness of thymoquinone in the treatment of experimental asthma. Clin. Ter. 2013, 164. [CrossRef]

224. Oguz, S.; Kanter, M.; Erboga, M.; Erenoglu, C. Protective effects of thymoquinone against cholestatic oxidative stress and hepatic damage after biliary obstruction in rats. J. Mol. Histol. 2012, 43, 151-159. [CrossRef]

225. Raghunandhakumar, S.; Paramasivam, A.; Senthilraja, S.; Naveenkumar, C.; Asokkumar, S.; Binuclara, J.; Jagan, S.; Anandakumar, P.; Devaki, T. Thymoquinone inhibits cell proliferation through regulation of G1/S phase cell cycle transition in N-nitrosodiethylamine-induced experimental rat hepatocellular carcinoma. Toxicol. Lett. 2013, 223, 60-72. [CrossRef]

226. Awad, A.S.; Kamel, R.; Sherief, M.A.E. Effect of thymoquinone on hepatorenal dysfunction and alteration of CYP3A1 and spermidine/spermine N-1-acetyl-transferase gene expression induced by renal ischaemia-reperfusion in rats. J. Pharm. Pharmacol. 2011, 63, 1037-1042. [CrossRef]

227. Bai, T.; Lian, L.H.; Wu, Y.L.; Wan, Y.; Nan, J.X. Thymoquinone attenuates liver fibrosis via PI3K and TLR4 signaling pathways in activated hepatic stellate cells. Int. Immunopharmacol. 2013, 15, 275-281. [CrossRef]

228. Zafeer, M.F.; Waseem, M.; Chaudhary, S.; Parvez, S. Cadmium-induced hepatotoxicity and its abrogation by thymoquinone. J. Biochem. Mol. Toxicol. 2012, 26, 199-205. [CrossRef]

229. Alenzi, F.Q.; El-Sayed El-Bolkiny, Y.; Salem, M.L. Protective effects of Nigella sativa oil and thymoquinone against toxicity induced by the anticancer drug cyclophosphamide. Br. J. Biomed. Sci. 2010, 67, 20-28. [CrossRef]

230. Jaswal, A.; Sinha, N.; Bhadauria, M.; Shrivastava, S.; Shukla, S. Therapeutic potential of thymoquinone against anti-tuberculosis drugs induced liver damage. Environ. Toxicol. Pharmacol. 2013, 36, 779-786. [CrossRef]

231. Nili-Ahmadabadi, A.; Tavakoli, F.; Hasanzadeh, G.R.; Rahimi, H.R.; Sabzevari, O. Protective effect of pretreatment with thymoquinone against Aflatoxin B1 induced liver toxicity in mice. DARU. J. Pharm. Sci. 2011, 19, 282-287.

232. Bai, T.; Yang, Y.; Wu, Y.L.; Jiang, S.; Lee, J.J.; Lian, L.H.; Nan, J.X. Thymoquinone alleviates thioacetamide-induced hepatic fibrosis and inflammation by activating LKB1-AMPK signaling pathway in mice. Int. Immunopharmacol. 2014, 19, 351-357. [CrossRef] [PubMed]

233. Elsherbiny, N.M.; El-Sherbiny, M. Thymoquinone attenuates Doxorubicin-induced nephrotoxicity in rats: Role of Nrf2 and NOX4. Chem. Biol. Interact. 2014, 223, 102-108. [CrossRef] [PubMed]

234. Evirgen, O.; Gökçe, A.; Ozturk, O.H.; Nacar, E.; Onlen, Y.; Ozer, B.; Motor, V.K. Effect of Thymoquinone on Oxidative Stress in Escherichia coli-Induced Pyelonephritis in Rats. Curr. Ther. Res. Clin. Exp. 2011, 72, 204-215. [CrossRef] [PubMed]

235. Shao, Y.Y.; Li, B.; Huang, Y.M.; Luo, Q.; Xie, Y.M.; Chen, Y.H. Thymoquinone attenuates brain injury via an antioxidative pathway in a status epilepticus rat model. Transl. Neurosci. 2017, 8, 9-14. [CrossRef]

236. Fanoudi, S.; Alavi, M.S.; Hosseini, M.; Sadeghnia, H.R. Nigella sativa and thymoquinone attenuate oxidative stress and cognitive impairment following cerebral hypoperfusion in rats. Metab. Brain Dis. 2019, 34, 1001-1010. [CrossRef]

237. Baghcheghi, Y.; Hosseini, M.; Beheshti, F.; Salmani, H.; Anaeigoudari, A. Thymoquinone reverses learning and memory impairments and brain tissue oxidative damage in hypothyroid juvenile rats. Arq. Neuropsiquiatr. 2018, 76, 32-40. [CrossRef]

238. Randhawa, M.A.; Alenazy, A.K.; Alrowaili, M.G.; Basha, J. An active principle of Nigella sativa L.; thymoquinone, showing significant antimicrobial activity against anaerobic bacteria. J. Intercult. Ethnopharmacol. 2017, 6, 97-101. [CrossRef]

239. Hayat, K.; Asim, M.R.; Nawaz, M.; Li, M.; Zhang, L.; Sun, N. Ameliorative effect of thymoquinone on ovalbumin-induced allergic conjunctivitis in Balb/c mice. Curr. Eye Res. 2011, 36, 591-598. [CrossRef]

240. Yurttaş, V.; Şereflican, M.; Erkoçoǧlu, M.; Dagli, M.; Terzi, E.H.; Flrat, T.; Seyhan, S. Comparison of histopathological effects of thymoquinone and local nasal corticosteroids in allergic rhinitis in a rabbit model. ORL 2016, 78, 55-60. [CrossRef]

241. McNabb-Baltar, J.; Jin, D.X.; Grover, A.S.; Redd, W.D.; Zhou, J.C.; Hathorn, K.E.; McCarty, T.R.; Bazarbashi, A.N.; Shen, L.; Chan, W.W. Lipase Elevation in Patients With COVID-19. Am. J. Gastroenterol. 2020, 115, 1286-1288. [CrossRef] [PubMed]

242. Satou, R.; Penrose, H.; Navar, L.G. Inflammation as a Regulator of the Renin-Angiotensin System and Blood Pressure. Curr. Hypertens Rep. 2018, 20, 100. [CrossRef] [PubMed]

243. Donoghue, M.; Hsieh, F.; Baronas, E.; Godbout, K.; Gosselin, M.; Stagliano, N.; Donovan, M.; Woolf, B.; Robison, K.; Jeyaseelan, R.; et al. A novel angiotensin-converting enzyme-related carboxypeptidase (ACE2) converts angiotensin I to angiotensin 1-9. Circ. Res. 2000, 87, E1-E9. [CrossRef] [PubMed]

244. Nishiga, M.; Wang, D.W.; Han, Y.; Lewis, D.B.; Wu, J.C. COVID-19 and cardiovascular disease: From basic mechanisms to clinical perspectives. Nat. Rev. Cardiol. 2020, 17, 543-558. [CrossRef]

245. Gheblawi, M.; Wang, K.; Viveiros, A.; Nguyen, Q.; Zhong, J.C.; Turner, A.J.; Raizada, M.K.; Grant, M.B.; Oudit, G.Y. AngiotensinConverting Enzyme 2: SARS-CoV-2 Receptor and Regulator of the Renin-Angiotensin System: Celebrating the 20th Anniversary of the Discovery of ACE2. Circ. Res. 2020, 126, 1456-1474. [CrossRef]

246. Berk, B.C.; Haendeler, J.; Sottile, J. Angiotensin II, atherosclerosis, and aortic aneurysms. J. Clin. Investig. 2000, 105, 1525-1526. [CrossRef]

247. Bruemmer, D.; Law, R.E. Thiazolidinedione regulation of smooth muscle cell proliferation. Am. J. Med. 2003, 115, 87-92. [CrossRef] 
248. Zhao, Q.; Zhang, J.; Wang, H. PGC- $1 \alpha$ limits angiotensin II-induced rat vascular smooth muscle cells proliferation via attenuating NOX1-mediated generation of reactive oxygen species. Biosci. Rep. 2015, 35, e00252. [CrossRef]

249. Wang, J.; Lv, X.W.; Shi, J.P.; Hu, X.S. Mechanisms involved in ceramide-induced cell cycle arrest in human hepatocarcinoma cells. World J. Gastroenterol. 2007, 13, 1129-1134. [CrossRef]

250. Kim, J.E.; Choi, H.C. Losartan inhibits vascular smooth muscle cell proliferation through activation of AMP-activated protein kinase. Korean J. Physiol. Pharmacol. 2010, 14, 299-304. [CrossRef]

251. Wang, K.; Gheblawi, M.; Oudit, G.Y. Angiotensin Converting Enzyme 2: A Double-Edged Sword. Circulation 2020, 142, 426-428. [CrossRef] [PubMed]

252. Penafuerte, C.A.; Gagnon, B.; Sirois, J.; Murphy, J.; Macdonald, N.; Tremblay, M.L. Identification of neutrophil-derived proteases and angiotensin II as biomarkers of cancer cachexia. Br. J. Cancer 2016, 114, 680-687. [CrossRef] [PubMed]

253. Mahmudpour, M.; Roozbeh, J.; Keshavarz, M.; Farrokhi, S.; Nabipour, I. COVID-19 cytokine storm: The anger of inflammation. Cytokine 2020, 133, 155151. [CrossRef] [PubMed]

254. Enayatfard, L.; Mohebbati, R.; Niazmand, S.; Hosseini, M.; Shafei, M.N. The standardized extract of Nigella sativa and its major ingredient, thymoquinone, ameliorates angiotensin II-induced hypertension in rats. J. Basic Clin. Physiol. Pharmacol. 2019, 30, 51-58. [CrossRef]

255. Pei, X.; Li, X.; Chen, H.; Han, Y.; Fan, Y. Thymoquinone Inhibits Angiotensin II-Induced Proliferation and Migration of Vascular Smooth Muscle Cells Through the AMPK/PPAR $\gamma /$ PGC-1 $\alpha$ Pathway. DNA Cell Biol. 2016, 35, 426-433. [CrossRef]

256. Idris-Khodja, N.; Schini-Kerth, V. Thymoquinone improves aging-related endothelial dysfunction in the rat mesenteric artery. Naunyn Schmiedebergs Arch. Pharmacol. 2012, 385, 749-758. [CrossRef]

257. Hosseinian, S.; Rad, A.K.; Bideskan, A.E.; Soukhtanloo, M.; Sadeghnia, H.; Shafei, M.N.; Motejadded, F.; Mohebbati, R.; Shahraki, S.; Beheshti, F. Thymoquinone ameliorates renal damage in unilateral ureteral obstruction in rats. Pharmacol. Rep. 2017, 69, 648-657. [CrossRef]

258. Carsana, L.; Sonzogni, A.; Nasr, A.; Rossi, R.S.; Pellegrinelli, A.; Zerbi, P.; Rech, R.; Colombo, R.; Antinori, S.; Corbellino, M.; et al. Pulmonary post-mortem findings in a series of COVID-19 cases from northern Italy: A two-centre descriptive study. Lancet Infect. Dis. 2020, 20, 1135-1140. [CrossRef]

259. Wichmann, D.; Sperhake, J.P.; Lütgehetmann, M.; Steurer, S.; Edler, C.; Heinemann, A.; Heinrich, F.; Mushumba, H.; Kniep, I.; Schröder, A.S.; et al. Autopsy Findings and Venous Thromboembolism in Patients With COVID-19: A Prospective Cohort Study. Ann. Intern. Med. 2020, 173, 268-277. [CrossRef]

260. Towhid, S.T.; Schmidt, E.M.; Schmid, E.; Münzer, P.; Qadri, S.M.; Borst, O.; Lang, F. Thymoquinone-induced platelet apoptosis. J. Cell. Biochem. 2011, 112, 3112-3121. [CrossRef]

261. Thummuri, D.; Jeengar, M.K.; Shrivastava, S.; Nemani, H.; Ramavat, R.N.; Chaudhari, P.; Naidu, V.G.M. Thymoquinone prevents RANKL-induced osteoclastogenesis activation and osteolysis in an in vivo model of inflammation by suppressing NF-KB and MAPK Signalling. Pharmacol. Res. 2015, 99, 63-73. [CrossRef] [PubMed]

262. Muralidharan-Chari, V.; Kim, J.; Abuawad, A.; Naeem, M.; Cui, H.; Mousa, S.A. Thymoquinone modulates blood coagulation in vitro via its effects on inflammatory and coagulation pathways. Int. J. Mol. Sci. 2016, 17, 474. [CrossRef] [PubMed]

263. Panigrahy, D.; Gilligan, M.M.; Huang, S.; Gartung, A.; Cortés-Puch, I.; Sime, P.J.; Phipps, R.P.; Serhan, C.N.; Hammock, B.D. Inflammation resolution: A dual-pronged approach to averting cytokine storms in COVID-19? Cancer Metastasis. Rev. 2020, 39, 337-340. [CrossRef] [PubMed]

264. Wang, D.; Dubois, R.N. Eicosanoids and cancer. Nat. Rev. Cancer. 2010, 10, 181-193. [CrossRef]

265. Serhan, C.N. Pro-resolving lipid mediators are leads for resolution physiology. Nature 2014, 510, 92-101. [CrossRef]

266. Shah, A. Novel Coronavirus-Induced NLRP3 Inflammasome Activation: A Potential Drug Target in the Treatment of COVID-19. Front. Immunol. 2020, 11, 1021. [CrossRef]

267. Umar, S.; Zargan, J.; Umar, K.; Ahmad, S.; Katiyar, C.K.; Khan, H.A. Modulation of the oxidative stress and inflammatory cytokine response by thymoquinone in the collagen induced arthritis in Wistar rats. Chem. Biol. Interact. 2012, 197, 40-46. [CrossRef]

268. Arjumand, S.; Shahzad, M.; Shabbir, A.; Yousaf, M.Z. Thymoquinone attenuates rheumatoid arthritis by downregulating TLR2, TLR4, TNF- $\alpha$ IL-1, and NFkB expression levels. Biomed. Pharmacother. 2019, 111, 958-963. [CrossRef]

269. Liu, Y.; Liao, R.; Qiang, Z.; Zhang, C. Pro-inflammatory cytokine-driven PI3K/Akt/Sp1 signalling and H2S production facilitates the pathogenesis of severe acute pancreatitis. Biosci. Rep. 2017, 37, BSR20160483. [CrossRef]

270. Hirota, S.A.; Ng, J.; Lueng, A.; Khajah, M.; Parhar, K.; Li, Y.; Lam, V.; Potentier, M.S.; Ng, K.; Bawa, M.; et al. NLRP3 inflammasome plays a key role in the regulation of intestinal homeostasis. Inflamm. Bowel Dis. 2011, 17, 1359-1372. [CrossRef]

271. Zaki, M.H.; Vogel, P.; Body-Malapel, M.; Lamkanfi, M.; Kanneganti, T.-D. IL-18 Production Downstream of the Nlrp3 Inflammasome Confers Protection against Colorectal Tumor Formation. J. Immunol. 2010, 185, 4912-4920. [CrossRef] [PubMed]

272. Chow, M.T.; Sceneay, J.; Paget, C.; Wong, C.S.F.; Duret, H.; Tschopp, J.; Möller, A.; Smyth, M.J. NLRP3 suppresses NK cell-mediated responses to carcinogen-induced tumors and metastases. Cancer Res. 2012, 72, 5721-5732. [CrossRef] [PubMed]

273. Elinav, E.; Strowig, T.; Kau, A.L.; Henao-Mejia, J.; Thaiss, C.A.; Booth, C.J.; Peaper, D.R.; Bertin, J.; Eisenbarth, S.C.; Gordon, J.I.; et al. NLRP6 inflammasome regulates colonic microbial ecology and risk for colitis. Cell 2011, 145, 745-757. [CrossRef] [PubMed]

274. Tu, S.; Bhagat, G.; Cui, G.; Takaishi, S.; Kurt-Jones, E.A.; Rickman, B.; Betz, K.S.; Penz-Oesterreicher, M.; Bjorkdahl, O.; Fox, J.G.; et al. Overexpression of Interleukin-1 $\beta$ Induces Gastric Inflammation and Cancer and Mobilizes Myeloid-Derived Suppressor Cells in Mice. Cancer Cell. 2008, 14, 408-419. [CrossRef] [PubMed] 
275. Bunt, S.K.; Yang, L.; Sinha, P.; Clements, V.K.; Leips, J.; Ostrand-Rosenberg, S. Reduced inflammation in the tumor microenvironment delays the accumulation of myeloid-derived suppressor cells and limits tumor progression. Cancer Res. 2007, 67, 10019-10026. [CrossRef]

276. Yang, Y.; Shen, C.; Li, J.; Yuan, J.; Yang, M.; Wang, F.; Li, G.; Li, Y.; Xing, L.; Peng, L.; et al. Exuberant elevation of IP-10, MCP-3 and IL-1ra during SARS-CoV-2 infection is associated with disease severity and fatal outcome. medRxiv 2020. [CrossRef]

277. Ghiringhelli, F.; Apetoh, L.; Tesniere, A.; Aymeric, L.; Ma, Y.; Ortiz, C.; Vermaelen, K.; Panaretakis, T.; Mignot, G.; Ullrich, E.; et al. Activation of the NLRP3 inflammasome in dendritic cells induces IL-1B-dependent adaptive immunity against tumors. Nat. Med. 2009, 15, 1170-1178. [CrossRef]

278. Houghton, P.J.; Zarka, R.; De Las Heras, B.; Hoult, J.R.S. Fixed oil of Nigella sativa and derived thymoquinone inhibit eicosanoid generation in leukocytes and membrane lipid peroxidation. Planta Med. 1995, 61, 33-36. [CrossRef]

279. Liu, X.; Chen, Z. The pathophysiological role of mitochondrial oxidative stress in lung diseases. J. Transl. Med. 2017, 15, 207. [CrossRef]

280. Nayak, B.S.; Pinto, S. Protein thiols and thiobarbituric acid reactive substance status in colon cancer patients. Scand. J. Gastroenterol. 2007, 42, 848-851. [CrossRef]

281. Gonçalves, T.L.; Erthal, F.; Corte, C.L.D.; Müller, L.G.; Piovezan, C.M.; Nogueira, C.W.; Rocha, J.B.T. Involvement of oxidative stress in the pre-malignant and malignant states of cervical cancer in women. Clin. Biochem. 2005, 38, 1071-1075. [CrossRef] [PubMed]

282. Guo, T.; Fan, Y.; Chen, M.; Wu, X.; Zhang, L.; He, T.; Wang, H.; Wan, J.; Wang, X.; Lu, Z. Cardiovascular Implications of Fatal Outcomes of Patients with Coronavirus Disease 2019 (COVID-19). JAMA Cardiol. 2020, 5, 811-818. [CrossRef] [PubMed]

283. Shah, K.S.; Yang, E.H.; Maisel, A.S.; Fonarow, G.C. The Role of Biomarkers in Detection of Cardio-toxicity. Curr. Oncol. Rep. 2017, 19, 42. [CrossRef] [PubMed]

284. Zilinyi, R.; Czompa, A.; Czegledi, A.; Gajtko, A.; Pituk, D.; Lekli, I.; Tosaki, A. The cardioprotective effect of metformin in doxorubicin-induced cardiotoxicity: The role of autophagy. Molecules 2018, 23, 1184. [CrossRef]

285. Zheng, Y.; Gu, S.; Li, X.; Tan, J.; Liu, S.; Jiang, Y.; Zhang, C.; Gao, L.; Yang, H.T. Berbamine postconditioning protects the heart from ischemia/reperfusion injury through modulation of autophagy. Cell Death Dis. 2017, 8, e2577. [CrossRef]

286. Su, Y.J.; Qu, Y.; Zhao, F.Y.; Li, H.F.; Mu, D.Z.; Li, X.H. Regulation of autophagy by the nuclear factor $\mathrm{kB}$ signaling pathway in the hippocampus of rats with sepsis. J. Neuroinflammation. 2015, 12, 116. [CrossRef]

287. Singhal, T. A Review of Coronavirus Disease-2019 (COVID-19). Indian J. Pediatr. 2020, 87, 281-286. [CrossRef]

288. Alqahtani, J.S.; Oyelade, T.; Aldhahir, A.M.; Alghamdi, S.M.; Almehmadi, M.; Alqahtani, A.S.; Almehmadi, M.; Alqahtani, A.S.; Quaderi, S.; Mandal, S.; et al. Prevalence, severity and mortality associated with COPD and smoking in patients with COVID-19: A rapid systematic review and meta-analysis. PLoS ONE 2020, 15, e0233147. [CrossRef]

289. Leung, J.M.; Yang, C.X.; Tam, A.; Shaipanich, T.; Hackett, T.L.; Singhera, G.K.; Dorscheid, D.R.; Sin, D.D. ACE-2 expression in the small airway epithelia of smokers and COPD patients: Implications for COVID-19. Eur. Respir. J. 2020, 55, 2000688. [CrossRef]

290. Parohan, M.; Yaghoubi, S.; Seraji, A. Liver injury is associated with severe coronavirus disease 2019 (COVID-19) infection: A systematic review and meta-analysis of retrospective studies. Hepatol. Res. 2020, 50, 924-935.

291. Subramaniam, S.R.; Cader, R.A.; Mohd, R.; Yen, K.W.; Ghafor, H.A. Low-dose cyclophosphamide-induced acute hepatotoxicity. Am. J. Case Rep. 2013, 14, 345-349. [PubMed]

292. Ming, Z.; Yongqiang, Z.; Zijin, Z.; Yan, X.; Di, C.; Xiaoxin, T. Severe and prolonged cyclophosphamide-induced hepatotoxicity in a breast cancer patient carrying a CYP2B67 variant. Pharmacogenomics 2019, 20, 1119-1124. [CrossRef] [PubMed]

293. Elefsiniotis, I.S.; Pantazis, K.D.; Ilias, A.; Pallis, L.; Mariolis, A.; Glynou, I.; Kada, H.; Moulakakis, A. 586 Tamoxifen (TMX)induced hepatotoxicity in breast cancer (BC) patients with pre-existing liver steatosis (LS). The role of glucose intolerance. J. Hepatol. 2004, 40, 171-172. [CrossRef]

294. De la Vega, M.C.L.; Zapater, P.; Such, J.; Sola-Vera, J.; Payá, A.; Horga, J.F.; Pérez-Mateo, M. Hepatitis tóxica asociada al uso de tamoxifeno. Presentación de un caso y revisión bibliográfica. Gastroenterol. Hepatol. 2002, 25, 247-250. [CrossRef]

295. Gabarre, P.; Dumas, G.; Dupont, T.; Darmon, M.; Azoulay, E.; Zafrani, L. Acute kidney injury in critically ill patients with COVID-19. Intensive Care Med. 2020, 46, 1339-1348. [CrossRef]

296. Li, A.; Zhang, W.; Zhang, L.; Liu, Y.; Li, K.; Du, G.; Qin, X. Elucidating the time-dependent changes in the urinary metabolome under doxorubicin-induced nephrotoxicity. Toxicol. Lett. 2020, 319, 204-212. [CrossRef]

297. Lu, Y.; Li, X.; Geng, D.; Mei, N.; Wu, P.Y.; Huang, C.C.; Jia, T.; Zhao, Y.; Wang, D.; Xiao, A.; et al. Cerebral Micro-Structural Changes in COVID-19 Patients-An MRI-based 3-month Follow-up Study: A brief title: Cerebral Changes in COVID-19. EClin. Med. 2020, 25,100484 .

298. Filatov, A.; Sharma, P.; Hindi, F.; Espinosa, P.S. Neurological Complications of Coronavirus Disease (COVID-19): Encephalopathy. Cureus 2020, 12, e7352. [CrossRef]

299. Su, S.; Shen, J.; Zhu, L.; Qiu, Y.; He, J.S.; Tan, J.Y.; Iacucci, M.; Ng, S.C.; Ghosh, S.; Mao, R.; et al. Involvement of digestive system in COVID-19: Manifestations, pathology, management and challenges. Therap. Adv. Gastroenterol. 2020, 13, 1756284820934626. [CrossRef]

300. Ozturker, Z.K. Conjunctivitis as sole symptom of COVID-19: A case report and review of literature. Eur. J. Ophthalmol. 2020. [CrossRef] 